\title{
Sirt3 Exerts Its Tumor-Suppressive Role by Increasing p53 and Attenuating Response to Estrogen in MCF-7 Cells
}

\author{
Marija Pinterić ${ }^{1,+}$, Iva I. Podgorski ${ }^{1,+}{ }^{+}$, Marijana Popović Hadžija ${ }^{1}\left(\mathbb{D}\right.$, Vedrana Filić $^{2}$, \\ Mladen Paradžik 2,3 (D), Bastien Lucien Jean Proust ${ }^{1}$, Ana Dekanić ${ }^{1}{ }^{\mathbb{D}}$, Ivan Ciganek ${ }^{1}$, \\ Denis Pleše ${ }^{1}$, Dora Marčinko ${ }^{1}$, Tihomir Balog ${ }^{1}$ and Sandra Sobočanec ${ }^{1, * \mathbb{D}}$ \\ 1 Division of Molecular Medicine, Ruđer Bošković Institute, 10000 Zagreb, Croatia; mpinter@irb.hr (M.P.); \\ iskrinj@irb.hr (I.I.P.); mhadzija@irb.hr (M.P.H.); Bastien.Lucien.Jean.Proust@irb.hr (B.L.J.P.); \\ adekanic@irb.hr (A.D.); iciganek@stud.biol.pmf.hr (I.C.); dplese@pharma.hr (D.P.); \\ dora.marcinko@krka.biz (D.M.); balog@irb.hr (T.B.) \\ 2 Division of Molecular Biology, Ruđer Bošković Institute, 10000 Zagreb, Croatia; \\ Vedrana.Filic.Mileta@irb.hr (V.F.); Mladen.Paradzik@irb.hr (M.P.) \\ 3 Department Molecular Biotechnology and Health Sciences, Molecular Biotechnology Centre (MBC), \\ University of Torino, 10124 Torino, Italy \\ * Correspondence: ssoboc@irb.hr; Tel.: +385-1-4561-172 \\ + These authors contributed equally to this work.
}

Received: 25 February 2020; Accepted: 30 March 2020; Published: 1 April 2020

check for updates

\begin{abstract}
Estrogen (E2) is a major risk factor for the initiation and progression of malignancy in estrogen receptor (ER) positive breast cancers, whereas sirtuin 3 (Sirt3), a major mitochondrial $\mathrm{NAD}^{+}$-dependent deacetylase, has the inhibitory effect on the tumorigenic properties of ER positive MCF-7 breast cancer cells. Since it is unclear if this effect is mediated through the estrogen receptor alpha $(E R \alpha)$ signaling pathway, in this study, we aimed to determine if the tumor-suppressive function of Sirt3 in MCF-7 cells interferes with their response to E2. Although we found that Sirt3 improves the antioxidative response and mitochondrial fitness of the MCF-7 cells, it also increases DNA damage along with p53, AIF, and ER $\alpha$ expression. Moreover, Sirt3 desensitizes cells to the proliferative effect of E2, affects p53 by disruption of the ER $\alpha$-p53 interaction, and decreases proliferation, colony formation, and migration of the cells. Our observations indicate that these tumor-suppressive effects of Sirt3 could be reversed by E2 treatment only to a limited extent which is not sufficient to recover the tumorigenic properties of the MCF-7 cells. This study provides new and interesting insights with respect to the functional role of Sirt3 in the E2-dependent breast cancers.
\end{abstract}

Keywords: sirtuin 3; MCF-7; estrogen receptor; p53; breast cancer cells

\section{Introduction}

$17 \beta$-estradiol (E2) is a steroid hormone essential for the maintenance of the female reproductive system with important physiological functions in the immune, cardiovascular, and neural systems [1,2]. However, E2 is a major risk factor for initiation and progression of malignancy in estrogen receptor (ER) positive breast cancers [3]. E2 mainly exerts its effect through the classical genomic pathway involving estrogen receptors alpha $(E R \alpha)$ and beta $(E R \beta)$ that function as transcription factors [4], with $E R \alpha$ being essential for proliferative signaling in both normal and breast cancer cells [5]. By binding to $\mathrm{ER} \alpha$, E2 promotes cellular proliferation through the upregulation of cell cycle regulating genes, and simultaneously triggers $\mathrm{ER} \alpha$ proteasomal degradation required for the cellular response to environmental E2 levels [6]. 
Sirtuin 3 (Sirt3), NAD $^{+}$dependent deacetylase, is the only member of the sirtuin family that is linked to longevity in humans. In addition, important cellular and mitochondrial processes, including reactive oxygen species (ROS) generation, are integrated through Sirt3. It has been shown that Sirt3 has a bifunctional role in cancer, acting as both oncoprotein and tumor suppressor, depending on the tissue and cancer-type specific metabolic programs [7]. We have recently shown that Sirt3 has the inhibitory effect on tumorigenic properties of $E R \alpha$ positive breast cancer cells, particularly when combined with hyperoxic treatment [8]. However, it is not clear if this effect is mediated through the $E R \alpha$ signaling pathway.

While ER $\alpha$ plays an important role in the progression of breast cancer, p53 functions as a major tumor suppressor through induction of target genes for cell cycle arrest and DNA repair [9]. Given that p53 functions primarily as a tumor suppressor, any aberration in the p53 gene or dysfunction of p53-mediated signaling pathway leads to cellular proliferation and potential tumorigenesis [10]. Breast cancer cells usually have functional p53, although its activity is altered by various mechanisms [11]. In ER $\alpha$ positive breast cancer cells, the abrogation of the $\mathrm{p} 53$ signaling pathway is a major event towards cancer progression, where $\mathrm{p} 53$ is functionally repressed by interaction with $\mathrm{ER} \alpha$ [12]. However, the mechanism underlying the inactivation of $\mathrm{p} 53$ function is not fully understood.

Although the elevated levels of ER $\alpha$ contribute to an increased risk of breast cancer [3], it has also been reported that $\mathrm{ER} \alpha$ overexpression can be associated with reduced metabolic potential and invasiveness [13]. Earlier studies have shown that low Sirt3 expression is associated with reduced survival in all breast cancers and highlighted its potential role as a biomarker to assist in identifying high risk patients [14]. Furthermore, it was also shown that the full-length nuclear Sirt3 can indirectly activate and prevent degradation of p53 in MCF-7 cells through deacetylation of phosphatase PTEN [15]. Considering the tumor suppressive role of Sirt3, we hypothesized that E2/ER $\alpha$ signaling can be negatively affected by Sirt3. So far, it has not been shown that Sirt3 exerts its tumor-suppressive function in MCF-7 cells by interfering with their response to E2.

Here, we report that overexpressed Sirt3 reduces the response of MCF-7 cells to E2, affects p53 by disruption of the ER $\alpha$-p53 interaction, and inhibits the clonogenic growth of MCF-7 cells. Thus, Sirt3 can be considered to reduce tumor-initiating capacity of these cells by attenuating response of the ER $\alpha$ positive breast cancer cells to the E2. These results provide new and interesting insights concerning the functional role of Sirt3 in breast cancer and its therapeutic potential in hormone-positive breast tumors.

\section{Materials and Methods}

\subsection{Cell Lines, Transfection, Treatments}

The MCF-7 cell line was obtained from Public Health England (London, UK; ECACC 86012803), tested for mycoplasma contamination, and was grown in high glucose Dulbecco's modified Eagle medium (DMEM, Sigma-Aldrich, St. Louis, MO, USA) with 10\% fetal bovine serum (FBS, Capricorn Scientific, Germany), 1\% nonessential amino acids (Sigma-Aldrich, St. Louis, MO, USA) and 1\% antibiotic/antimycotic solution (Capricorn Scientific, Germany) at $37{ }^{\circ} \mathrm{C}$ with $5 \% \mathrm{CO}_{2}$ in a humidified atmosphere. Due to the commercial source of the cells, there was no need to authenticate them prior to the study. The MCF-7 cells were transfected with the FLAG-tagged Sirt3 (MCF-7S3) or empty pcDNA3.1 plasmid (MCF-7C), as described previously in [8]. To examine the E2 effect on the characteristics of E2-dependent cell growth, we used white DMEM medium with steroid free (charcoal treated) serum (Sigma-Aldrich, St. Louis, MO, USA), since it is known that phenol red can activate ER $\alpha$ gene regulation [16,17]. Therefore, in our study, both phenol red and white DMEM (Capricorn Scientific, Germany) were used, depending on the parameters examined. For the experiments in white DMEM, cells were grown in this media for one week before the experiments. In our research, we treated cells with $10 \mathrm{nM}$ E2 (17ß-estradiol, Sigma-Aldrich, St. Louis, MO, USA) for $2 \mathrm{~h}$ and if we wanted to confirm that E2 effect was mediated by ER $\alpha$, we treated cells with ER $\alpha$ inhibitor $100 \mathrm{nM} \mathrm{ICI} \mathrm{(ICI} \mathrm{182,780;} \mathrm{Santa}$ Cruz Biotechnology, Dallas, TX, USA) $2 \mathrm{~h}$ before adding E2. 


\subsection{RNA Isolation, Reverse Transcription, and $q P C R$ Analysis}

Total RNA was isolated from $\sim 10^{6}$ cells using TRIzol reagent (Invitrogen, Carlsbad, CA, USA) according to the manufacturer's instructions. Relative gene expression of sirt-3 (Hs00953477_m1, TaqMan, Thermo Fisher Scientific, Waltham, MA, USA) and esr-1 (Hs01046816_m1, TaqMan, Thermo Fisher Scientific, Waltham, MA, USA) were quantified by reverse transcription of total RNA and real-time quantitative PCR (qPCR) analysis. Data were analyzed using the $2^{-\Delta \Delta C t}$ method and presented as the fold change in gene expression normalized to endogenous reference gene ( $\beta$-actin; Hs01060665_g1, TaqMan, Thermo Fisher Scientific, Waltham, MA, USA) and relative to the control. All reactions were carried out in triplicate.

\section{3. siRNA-Mediated Silencing of Sirt3 and ER $\alpha$ Expression}

Silencing of Sirt3 and ER $\alpha$ expression was done using Lipofectamine2000 (Thermo Fisher Scientific, Waltham, MA, USA) according to the manufacturer's guidelines. Sirt3 siRNA (siSirt3), ER $\alpha$ siRNA $(\operatorname{siER} \alpha)$, and scrambled control siRNA (siSCR) were obtained from Ambion (Thermo Fisher Scientific, Waltham, MA, USA). Cells $\left(10^{5}\right)$ were seeded on a 24 -well plate, and $24 \mathrm{~h}$ later transfected with $100 \mathrm{nM}$ siRNA for $48 \mathrm{~h}$, followed by protein collection and Western blot analysis for targeted proteins.

\subsection{Fractionation, SDS-PAGE, and Western Blot Analysis}

For fractionation analysis, $2 \times 10^{6}$ cells were seeded on $10 \mathrm{~cm}$ Petri dish and $24 \mathrm{~h}$ later treated with ICI and E2, followed by fractionation by Cell Fractionation Kit Standard (ab109719, Abcam, UK) according to the manufacturer's instructions. Proteins of obtained fractions were measured by Pierce ${ }^{\mathrm{TM}}$ BCA Protein Assay Kit (Thermo Fischer Scientific, Waltham, MA, USA) and prepared in SDS-PAGE sample buffer (100 mM Tris- $\mathrm{HCl}$ (pH 6,8), 2\% SDS, 20\% glycerol, $4 \% \beta$-mercaptoethanol, $0.5 \%$ bromophenol blue dye) for Western blot analysis. Anti-GAPDH and anti-H3 antibodies were used as controls for purity of cytoplasmic and nuclear fractions, respectively $[18,19]$. Total cellular proteins for Western blot analysis were isolated in Ripa buffer with protease inhibitors (Roche, Basel, Switzerland). SDS-PAGE and Western blot analysis were carried out as described previously in [8]. Primary and secondary antibodies used in this study are listed in Supplementary Table S1.

\subsection{Immunofluorescence, Micronucleated Cells and Confocal Microscopy}

Immunofluorescence analysis was performed as described previously in [20]. When MitoTracker Deep Red (Thermo Fisher Scientific, Waltham, MA, USA) was used, cells were labelled with $100 \mathrm{nM}$ MitoTracker for 20 minutes before the end of the E2 treatment. Primary and secondary antibodies used in this study are listed in Supplementary Table S2. DAPI (4,6-diamidino-2-fenilindol, Sigma-Aldrich, St. Louis, MO, USA) was used for nuclear staining. For detection of micronucleated cells, $10^{4}$ cells/well were seeded on coverslips in a 24-well plate and were grown in white DMEM for 10 days, then fixed with $4 \%$ PFA, and stained with $5 \mu \mathrm{M}$ Hoechst 33342 (Sigma-Aldrich, St. Louis, MO, USA) for $10 \mathrm{~min}$. As a positive control, formation of micronucleated cells in MCF-7C clone was induced with $400 \mu \mathrm{M}$ $\mathrm{H}_{2} \mathrm{O}_{2}$ for $4 \mathrm{~h}$ after which they were left to grow in fresh DMEM for the next $72 \mathrm{~h}$, and then were further processed and analyzed as untreated cells. Confocal imaging was performed by sequential scanning using a Leica TCS SP8 X laser scanning microscope (Leica Microsystems, Germany), equipped with a HC PL APO CS2 63/1.40 oil immersion objective and a white light laser. The excitation wavelengths and emission detection ranges used were $350 \mathrm{~nm}$ and 412 to $460 \mathrm{~nm}$ for Hoechst 33342, $405 \mathrm{~nm}$ and 412 to $460 \mathrm{~nm}$ for DAPI, $488 \mathrm{~nm}$ and 495 to $550 \mathrm{~nm}$ for Alexa488, $594 \mathrm{~nm}$ and 601 to $644 \mathrm{~nm}$ for Alexa594, and $644 \mathrm{~nm}$ and 651 to $700 \mathrm{~nm}$ for MitoTracker Deep Red, respectively.

\subsection{Cellular Proliferation, Metabolic Activity, Clonogenic Capacity}

In order to determine the cell proliferation, EdU Click-iT ${ }^{\circledR}$ assay (Thermo Fisher Scientific, Waltham, MA, USA) was used according to the manufacturer's instructions [21]. Briefly, $4 \times 10^{5}$ cells 
were seeded in six-well plates in both red and white DMEM, $24 \mathrm{~h}$ later they were treated with E2 and ICI, and left to grow for an additional $48 \mathrm{~h}$. The samples were analyzed using FACS Calibur flow cytometer (BD Biosciences, Franklin Lakes, NJ, USA), while acquisition was made using the CellQuest software package (BD Biosciences, Franklin Lakes, NJ, USA). The analysis of the frequencies of proliferative (EdU positive) cells was performed using the FCS Express 3 software package (De Novo software, Pasadena, CA, USA). For the MTT(3-(4,5-dimethylthiazol-2-yl)-2,5-diphenyl tetrazolium bromide; tetrazolium dye) assay, $5 \times 10^{3}$ cells were seeded in a 96-well plate and $24 \mathrm{~h}$ later treated with ICI and E2 and processed as described previously in [8]. For the clonogenic capacity (CFU) assay, $2 \times 10^{3}$ cells were seeded in $5 \mathrm{~cm}$ Petri dishes, and $24 \mathrm{~h}$ later treated with ICI and E2. After that, the cells were incubated for 14 days until the visible colonies were observed and processed as previously described [8].

\subsection{Migration Assay}

For monitoring cell migration, $1 \times 10^{5}$ cells were treated for $2 \mathrm{~h}$ with E2 in serum-reduced DMEM, seeded in migration Transwell Cell Culture Inserts (pore size $8 \mathrm{~mm}$; Corning, Corning, NY, USA), and left to migrate for $22 \mathrm{~h}$ towards 10\% FBS in DMEM as a chemoattractant. Cells migrated to the underside of the filter were fixed with 4\% PFA, stained with $1 \%$ crystal violet solution, photographed, and quantified using NIH ImageJ (v1.52a, U.S. National Institutes of Health, Bethesda, MD, USA).

\subsection{Measurements of Mitochondrial Membrane Potential, Cytosolic, and Mitochondrial ROS Production}

Quantitative analysis of mitochondrial membrane potential $(\Delta \Psi \mathrm{m})$, and mitochondrial superoxide production (mtROS) was carried out using $100 \mathrm{nM}$ MitoTracker Deep Red and $5 \mu$ M MitoSOX Red reagent (both from Thermo Fisher Scientific, Waltham, MA, USA), respectively. Cytosolic ROS production was measured with $20 \mu \mathrm{M}$ dihydroethidium (DHE) (Invitrogen Molecular Probes, Carlsbad, CA, USA). Sytox Red (500 nM, Thermo Fisher Scientific, Waltham, MA, USA) and PI (1.5 $\mu \mathrm{g} / \mathrm{mL})$ were used for exclusion of dead cells dyed with MitoSOX Red or DHE, and MitoTracker Deep Red, respectively. The samples were analyzed using a FACS Calibur flow cytometer as described above.

\subsection{Antioxidant Enzyme Activities}

Superoxide dismutase (SOD) activity was assayed with a RANSOD kit (RANDOX Labs, UK) according to the manufacturer's protocol. The SOD-2 activity was determined under identical conditions with the addition of $4 \mathrm{mM} \mathrm{KCN}$ in the assay buffer for $30 \mathrm{~min}$ to inhibit SOD1. The SOD1 activity was obtained by subtracting the SOD2 activity from the total SOD activity. Lyophilized cells and standard solutions were used for the SOD assay. The absorbance was measured at $505 \mathrm{~nm}$ on a microplate reader (Bio-Tek Instruments, Inc., Winooski, VT, USA).

\subsection{Immunoprecipitation and Coimmunoprecipitation}

Cells were seeded in white DMEM and $24 \mathrm{~h}$ later treated with E2 for $2 \mathrm{~h}$, followed by cell lysis in Co-IP buffer (250 mM NaCl, 0,1\% NP-40, 50 mM HEPES). Since Sirt3 is FLAG-tagged, ANTI-FLAG M2 affinity gel (Sigma-Aldrich, St. Louis, MO, USA) was used for Sirt3 coimmunoprecipitation. For ER $\alpha$, anti-ER $\alpha$ antibody (F-10, Santa Cruz Biotechnology, Dallas, TX, USA) was used and Pierce Crosslink Immunoprecipitation Kit (Thermo Fisher Scientific, Waltham, MA, USA) according to the manufacturer's guidelines, with the exception of the Co-IP buffer instead of IP Lysis/Wash Buffer from the kit.

\subsection{Statistical Analysis}

Statistical analysis of data was performed using R v2.15.3 (CRAN, http://cran.r-project.org) and RStudio for Windows, v0.97 (http://www.rstudio.com/) and SPSS for Windows (17.0, IBM, Armonk, NY, USA). Before all analyses, the samples were tested for normality of distribution using the Shapiro-Wilk 
test. If the data followed a non-Gaussian distribution, the following nonparametric analyses were performed: Kruskal-Wallis non-parametric ANOVA for testing differences between groups that do not follow normal distribution, followed by Wilcoxon signed-rank test for testing differences between two related groups. In the case of normal distributions, the following parametric tests were performed: two-way ANOVA, followed by Bonferroni adjustments for the analysis of (simple) main effects. For comparisons of the two samples, the Student's t-test or Mann-Whitney U test were used, depending on the distribution of data. Significance was set at $p<0.05$.

\section{Results}

3.1. Sirt3 Participates in Regulation of ER $\alpha$ Expression and Localization and Alters Its Response to E2 Treatment in MCF-7 Cells

To examine if and how Sirt3 affects ER $\alpha$ expression, first, we stably overexpressed Sirt3 in MCF-7 cells (hereafter MCF-7S3) since MCF-7 cells express Sirt3 at almost undetectable levels (Figure 1A,C and Figure 2). Then, we analyzed mRNA and protein expression level of ER $\alpha$ in both MCF-7S3 and MCF-7 cells transfected with empty plasmid as a negative control (hereafter MCF-7C) (Figure 1B,C). Because MCF-7 cells proliferate in an E2-dependent manner [22], we next tested how E2 addition affected its cognate receptor ER $\alpha$ in the absence and presence of Sirt3. We found a positive effect of Sirt3 on both esr-1 gene transcript and protein expression level, with +2.1 -fold change and 30\% increase in the absence of E2, respectively (Figure 1B,C). In the absence of Sirt3, E2 addition increased ER $\alpha$ protein expression $(p<0.01)$, whereas in Sirt3 clones it caused reduction of already upregulated ER $\alpha$ protein level $(p<0.01)$. Antiestrogen ICI, which was added two hours prior to E2 addition, had an inhibitory effect on ER $\alpha$ expression in both cell lines (Figure 1C, $p<0.001$ ). We also examined the effects of Sirt3 or ER $\alpha$ silencing on ER $\alpha$ and Sirt3 expression (Figure 1D) and showed that Sirt3 silencing lowers the expression of $E R \alpha(p<0.01)$. Furthermore, we investigated the effect of Sirt3 on cellular localization of $E R \alpha$. Using the fractionation method, we found that E2 treatment promoted nuclear accumulation of $\mathrm{ER} \alpha$ in both cell lines $(p<0.001)$, whereas a lower signal observed in cells treated with ICI prior to E2 addition indicated degradation of ER $\alpha$. Interestingly, Sirt3 overexpression slightly delocalizes ER $\alpha$ in the cytosol (Figure 1E, $p<0.001$ ). Confocal microscopy confirmed the primary localization of ER $\alpha$ in the nucleus (Figure 2). These results collectively indicate, while E2 affects both localization and the abundance of ER $\alpha$ expression, Sirt3 only affects the amount of ER $\alpha$ expressed in the cell.

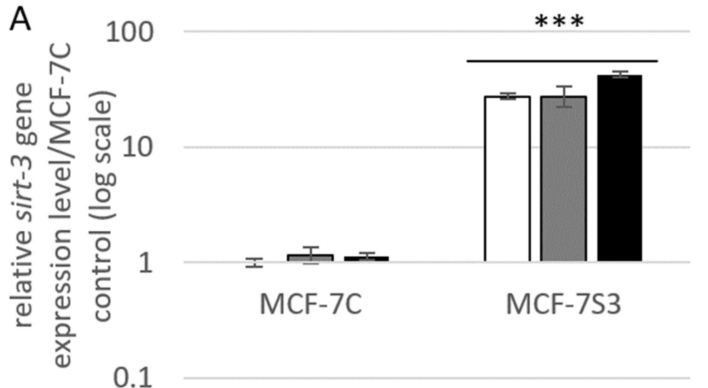

$\square$ control $\square \mathrm{E} 2 \quad \square \mathrm{E} 2+\mathrm{ICl}$
B

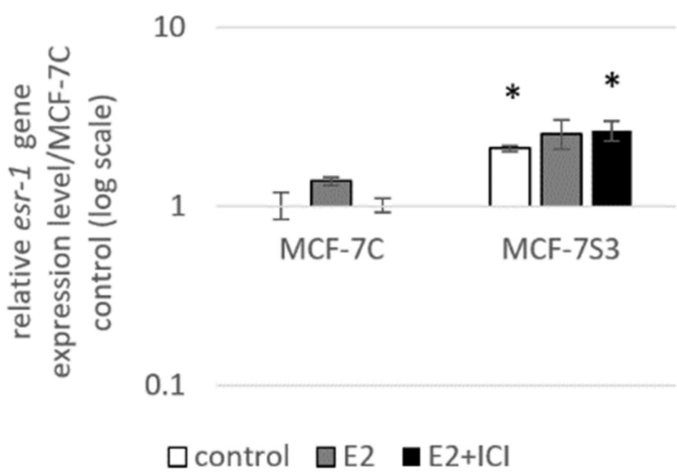

Figure 1. Cont. 
C
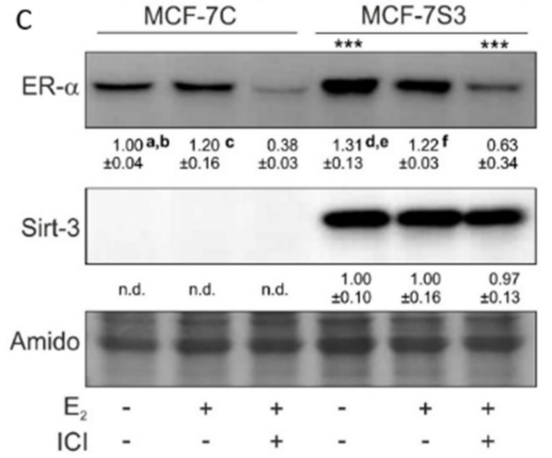

E
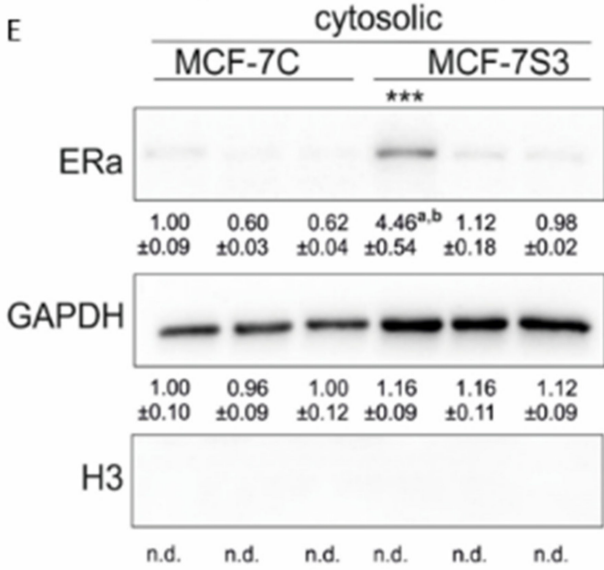

$\begin{array}{lllllll}\mathrm{E} 2 & - & + & + & - & + & + \\ \mathrm{ICl} & - & - & + & - & - & +\end{array}$

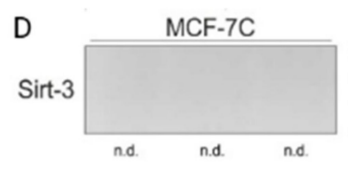

MCF-7S3

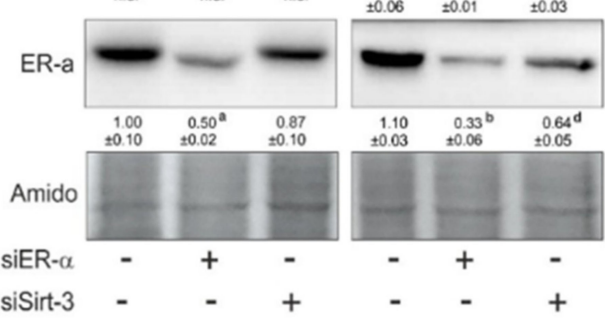

nuclear

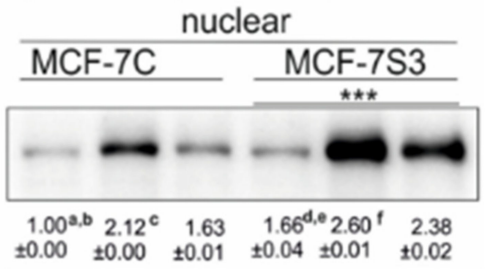

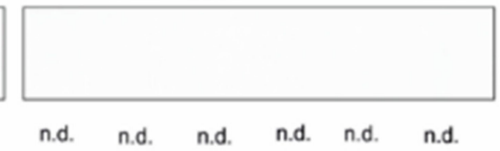

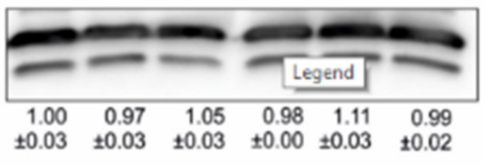

$-++-+$

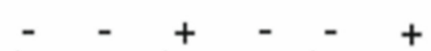

Figure 1. Sirt3 regulates ER $\alpha$ expression and localization. (A) Expression of sirt-3 gene was significantly increased in MCF-7S3 clones as compared with MCF-7C (*** $p<0.001)$. The results are presented as fold change \pm SE on a log-scale, normalized to the control MCF-7C. Experiments were repeated at least three times (hereafter referred to as $n \geq 3$ ); (B) Expression of $e s r-1$ gene was significantly increased in the control and E2 + ICI-treated MCF-7S3 clones as compared with MCF-7C (* $p<0.05)$; (C) Immunoblots of ER $\alpha$ and Sirt3 protein expression level. Two-way ANOVA revealed significant interaction effect between Sirt3 and treatment on $\operatorname{ER} \alpha \mathrm{F}(2,12)=9.321, p=0.004$, partial $\eta^{2}=0.608$; higher in the control (*** $p<0.001)$ and E2 + ICI-treated (*** $p<0.001)$ MCF-7S3 vs. MCF-7C. In MCF-7C, higher in E2 vs. the control ( $\left.{ }^{\mathrm{a}} p<0.01\right)$ and E2 + ICI-treated $\left({ }^{\mathrm{c}} p<0.001\right)$ and in the control vs. E2 + ICI-treated $\left({ }^{\mathrm{b}} p<0.001\right)$. In MCF-7S3, higher in the control vs. E2 ( $\left.{ }^{\mathrm{d}} p<0.01\right)$ and $\mathrm{E}_{2}+$ ICI-treated ( $\left.{ }^{\mathrm{e}} p<0.001\right)$ and in E2 vs. $\mathrm{E}_{2}+\mathrm{ICI}$-treated ( ${ }^{\mathrm{f}} p<0.001$ ); (D) Immunoblots of ER $\alpha$ and Sirt3 protein expression level in the cells transfected with scrambled (siSCR) control or siER- $\alpha$ and siSirt3 RNA. Lower ER $\alpha$ in the siER- $\alpha$-treated vs. siSCR MCF-7C cells ( $\left.{ }^{\mathrm{a}} p<0.05\right)$ and MCF-7S3 cells ( $\left.{ }^{\mathrm{b}} p<0.01\right)$. In MCF-7S3, lower Sirt3 $\left({ }^{\mathrm{c}} p<0.05\right)$ and ER $\alpha\left({ }^{\mathrm{d}} p<0.01\right)$ in the siSirt3-treated cells; (E) Immunoblots of ER $\alpha$ protein expression in cellular fractions. For cytosolic fraction, two-way ANOVA revealed a significant interaction effect between Sirt3 and treatment $F(2,12)=54.61, p<0.001$, partial $\eta^{2}=0.948$; higher cytosolic ER $\alpha$ in the control MCF-7S3 vs. MCF-7C ( $\left.{ }^{* * *} p<0.001\right)$. In MCF-7S3, higher cytosolic ER $\alpha$ in the control vs. E2 $\left({ }^{\mathrm{a}} p<0.001\right)$ and E2 + ICI-treated group $\left({ }^{\mathrm{b}} p<0.001\right)$. For nuclear fraction, two-way ANOVA revealed significant interaction effect between Sirt3 and treatment F $(2,12)=1054.57, p<0.001$, partial $\eta^{2}=0.997$; higher nuclear ER $\alpha$ in MCF-7S3 vs. MCF-7C (*** $p<0.001)$. In MCF-7C, lower nuclear ER $\alpha$ in the control vs. E2 ( $\left.{ }^{\mathrm{a}} p<0.001\right)$ and E2 + ICI-treated group $\left({ }^{\mathrm{b}} p<0.001\right)$; higher nuclear ER $\alpha$ in E2 vs. E2 + ICI-treated group ( $\left.{ }^{c} p<0.001\right)$. In MCF-7S3, lower nuclear ER $\alpha$ in the control vs. E2 ( $\left.{ }^{\mathrm{d}} p<0.001\right)$ and E2 + ICI-treated group ( $\left.{ }^{\mathrm{e}} p<0.001\right)$ and higher nuclear ER $\alpha$ in E2 vs. E2 + ICI-treated group ( $\left.{ }^{\mathrm{f}} p<0.001\right)$. For (C), (D) and (E) results are shown as a ratio of the mean \pm SD normalized to the control MCF-7C $(n \geq 3)$. Amidoblack was used as a loading control. 


\subsection{Sirt3 Does Not Interact with ER $\alpha$ in MCF-7 Cells}

Since the presence of ER $\alpha$ in mitochondria has been described by several studies [23,24], we next investigated the possibility that $\mathrm{ER} \alpha$ resides inside mitochondria and interacts with Sirt3. Using both coimmunoprecipitation and confocal imaging, we found no interaction between ER $\alpha$ and Sirt3 (Supplementary Figure S1) or colocalization signal for ER $\alpha$ and Sirt3, respectively (Figure 2). These results collectively suggest that Sirt3 indirectly participates in the regulation of ER $\alpha$ expression.

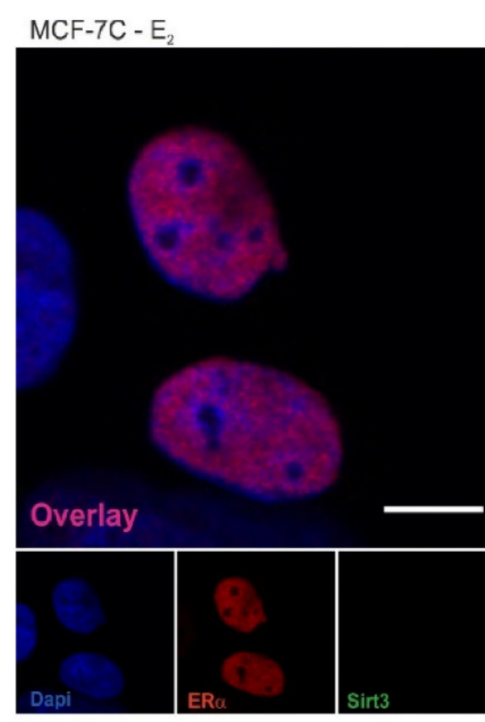

MCF-7S3 - E
MCF-7C + E

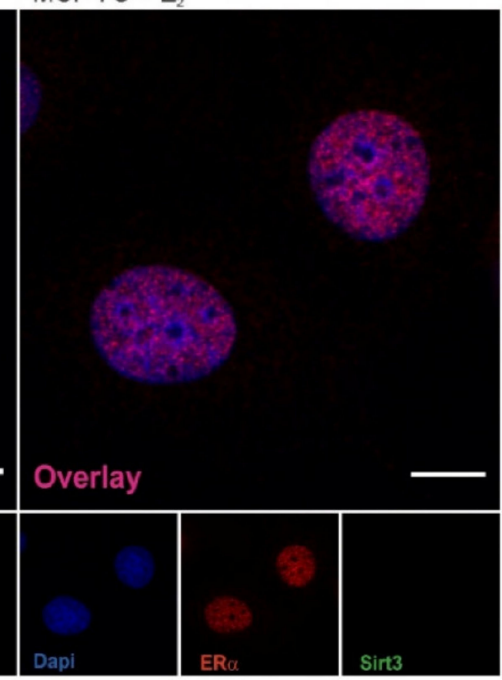

$\mathrm{MCF}-7 \mathrm{~S} 3+\mathrm{E}_{2}$
MCF-7C $+\mathrm{E}_{2}+\mid \mathrm{Cl}$

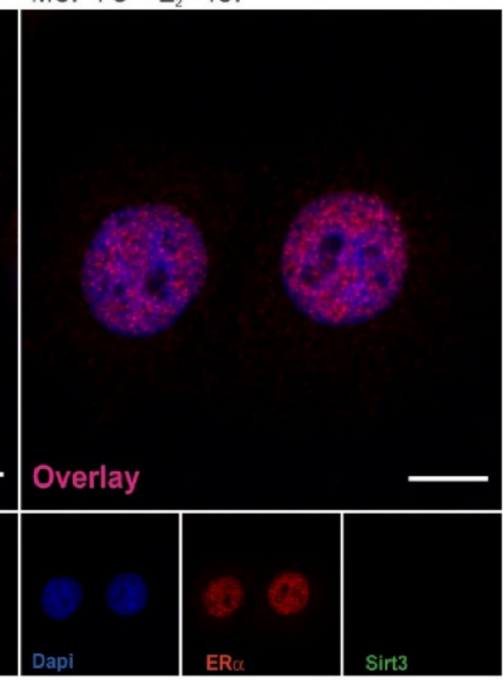

$\mathrm{MCF}-7 \mathrm{~S} 3+\mathrm{E}_{2}+\mid \mathrm{Cl}$

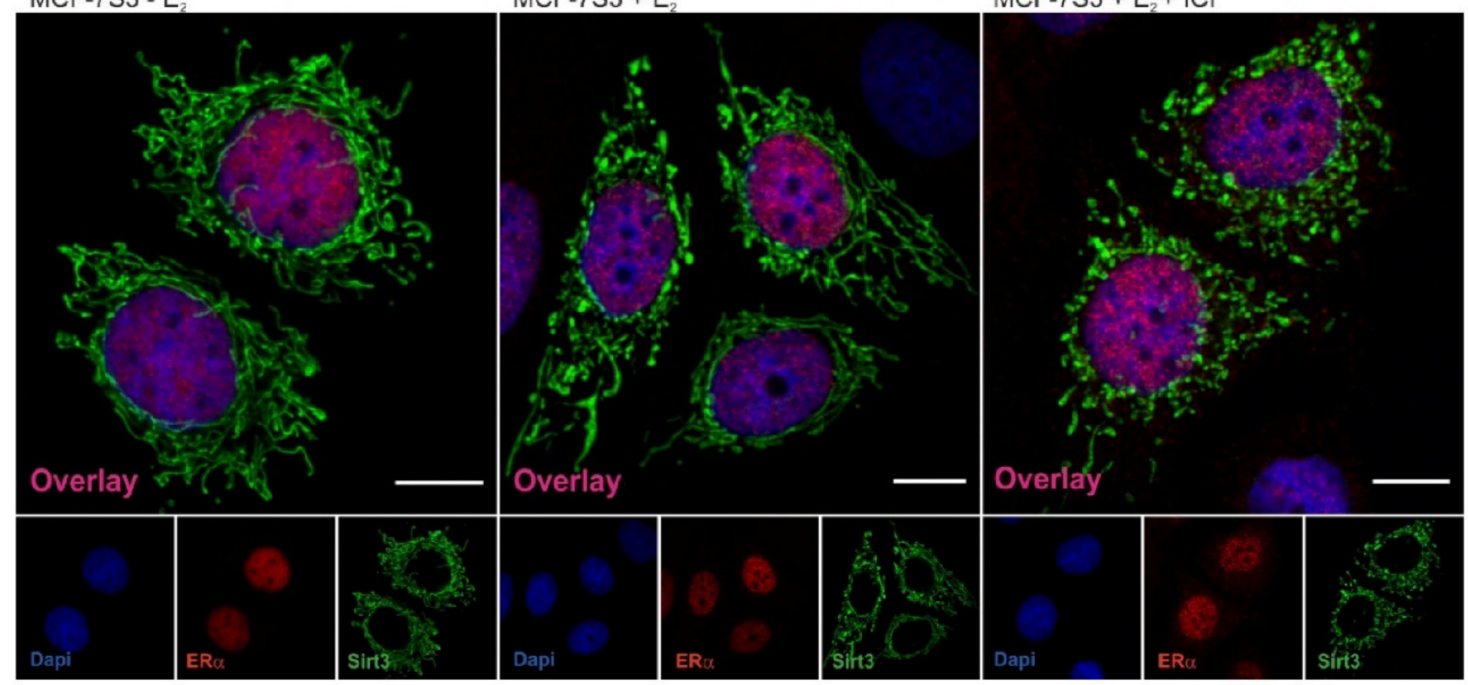

Figure 2. Sirt3 does not colocalize with ER $\alpha$ in MCF-7 cells. Confocal imaging of ER $\alpha$ localization in control, E2, and E2 + ICI-treated MCF-7C and MCF-7S3 cells. Bar represents $10 \mu \mathrm{m}$.

\subsection{Sirt3 Amplifies E2-Induced Metabolic Activity and Mitochondrial Fitness of MCF-7 Cells}

To explore if Sirt3 plays a role in E2-induced metabolic activity of MCF-7 cells [25], we measured several parameters of mitochondrial function. First, we tested the effect of E2 and Sirt3 on metabolic activity of MCF-7 cells using MTT assay. The MTT salt is reduced to formazan in the metabolically active cells predominantly by mitochondrial complex-II subunit succinate dehydrogenase A (SDH-A) and is considered to be a marker of metabolic potential of the cell [26]. The Sirt3-overexpressing cells had significantly higher basal metabolic activity $(p<0.001)$ and Sirt3 further enhanced the inducing effect of E2 (Figure 3A), while ICI effectively abolished E2-induced metabolic activity to control levels in both cell lines. This result was confirmed with the observed protein expression levels of SDH-A 
(Figure 3B), indicating the combined effect of E2 and Sirt3 and involvement of ER $\alpha$ in the regulation of metabolic activity in MCF-7 cells. Furthermore, the expression levels of respiratory complex I (NDUFA9) and III (UQCRC2) were also elevated in Sirt3 overexpressors $(p<0.001)$, although with no significant effect of E2 (Figure 3B). Another marker of mitochondrial functionality is the mitochondrial membrane potential $(\Delta \Psi \mathrm{m})$ which plays a key role in mitochondrial homeostasis [27]. While in the absence of Sirt3, $\Delta \Psi \mathrm{m}$ remained unaffected by E2 or ICI addition, the MCF-7S3 cells exhibited increased basal $\Delta \Psi \mathrm{m}(p=0.003)$, which was further enhanced by E2 addition and abolished by ICI (Figure 3C, $p<0.001$ ). These results collectively suggest that (a) Sirt3 acts synergistically with E2 to induce metabolic activity, (b) E2-induced rise in mitochondrial potential is Sirt3 dependent, and (c) $\mathrm{ER} \alpha$ is involved in Sirt3-mediated mitochondrial fitness of MCF-7 cells.
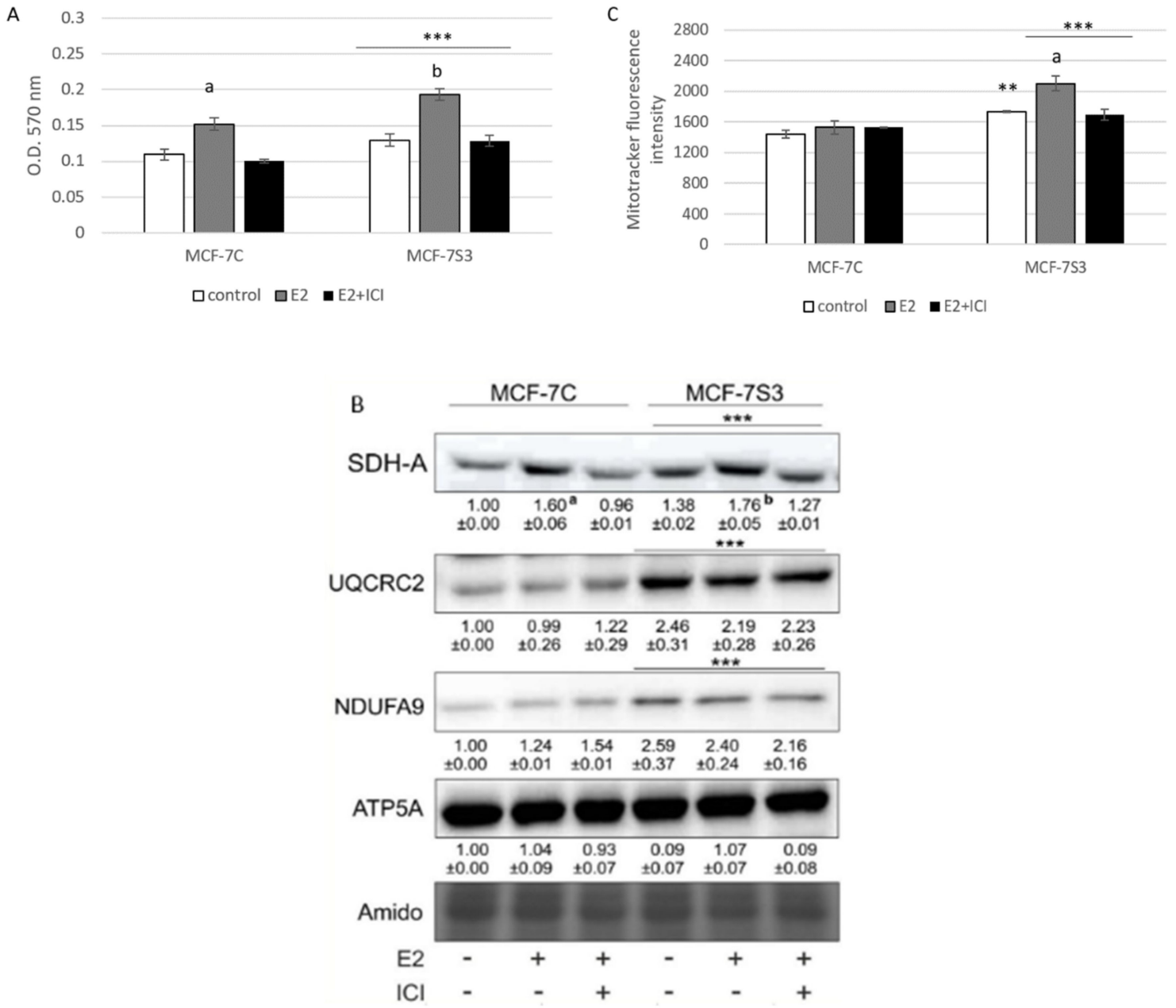

Figure 3. Sirt3 amplifies E2-induced metabolic activity and mitochondrial fitness of MCF-7 cells. (A) Metabolic activity measured with MTT assay. Two-way ANOVA revealed significant interaction effect between Sirt3 and treatment on metabolic activity $\mathrm{F}(2,34)=7.051, p=0.003$, partial $\eta^{2}=0.293$; *** $p<0.001$ MCF-7S3 vs. MCF-7C. In MCF-7C, higher in E2 vs. other groups ( $\left.{ }^{a} p<0.001\right)$. In MCF-7S3, higher in E2-treated vs. other groups $\left({ }^{\mathrm{b}} p<0.001\right)$. Results are shown as mean $\pm \mathrm{SD}(n \geq 3)$; (B) Immunoblots of mitochondrial respiration complexes. Two-way ANOVA revealed significant interaction effect between Sirt3 and treatment on SDH-A expression $\mathrm{F}(2,6)=10,846, p=0.010$, partial $\eta^{2}=0.783 ;{ }^{* * *} p<0.001$ MCF-7C vs. MCF-7S3 cells. In MCF-7C, higher SDH-A expression in E2-treated vs. other groups ( ${ }^{\mathrm{a}} p<0.001$ ). In MCF-7S3, higher SDH-A expression in E2-treated vs. other groups ( $\left.{ }^{\mathrm{b}} p<0.001\right)$. Higher UQCRC2 and NDUFA9 protein expression in MCF-7S3 cells as compared with 
MCF-7C (*** $p<0.001)$. Results are shown as mean \pm SD normalized to the control MCF-7C $(n \geq 3)$. Amidoblack was used as a loading control and representative immunoblots are shown; (C) Mitochondrial membrane potential $(\Delta \Psi \mathrm{m})$ measured with MitoTracker Deep Red dye using flow cytometry. Two-way ANOVA revealed significant interaction effect between Sirt3 and treatment F $(2,12)=11,019, p=0,010$, partial $\eta^{2}=0.786$; higher $\Delta \Psi \mathrm{m}$ in the control ( $\left.{ }^{* *} p=0.003\right)$, E2, and E2 + ICI-treated (*** $p<0.001)$ MCF-7S3 vs. MCF-7C. In MCF-7S3, higher $\triangle \Psi \mathrm{m}$ in E2 vs. the control and E2

+ ICI-treated ( $\left.{ }^{\mathrm{a}} p<0.001\right)$. Results are shown as mean \pm S.D $(n \geq 3)$.

3.4. Sirt3 Enhances Antioxidative Enzyme Activities and Cytosolic ROS, but Opposes E2-Induced Cytosolic and $m$ tROS Production

Since it is known that Sirt3 mediates mitochondrial oxidative pathways and regulates production of ROS (reviewed by [28]), we aimed to analyze the antioxidant enzyme system in MCF-7S3 cells. We found that MCF-7S3 cells exhibited significantly increased activities of two major antioxidative enzymes, mitochondrial manganese-dependent superoxide dismutase MnSOD (SOD2, Figure 4A, $p<0.001$ ) and cytosolic copper zinc-dependent superoxide dismutase CuZnSOD (SOD1, Figure 4B, $p<0.001)$, which was also confirmed by decreased expression level of inactive, acetylated form of MnSOD, AcSOD2 (Figure 4C, $p<0.001$ ). Moreover, protein levels of the catalase (Cat) and transcription nuclear factor erythroid 2-related factor 2 (Nrf2), a major activator of antioxidant response, were also upregulated in Sirt3-overexpressing cells (Figure $4 \mathrm{C}, p<0.001$ ). Next, we examined the role of E2 in the activation of antioxidant enzyme system. While having a positive effect on the activation of CuZnSOD $(p<0.001)$, Cat $(p<0.001)$, and Nrf2 $(p<0.01)$ in the control cells, in Sirt3 overexpressors, E2 failed to further increase their already elevated levels (Figure $4 \mathrm{~B}, \mathrm{C}$ ). Collectively, these results indicate that Sirt3-overexpressing cells exhibit a higher antioxidative response regardless of the E2 treatment. Due to the elevated antioxidant enzyme system in the MCF-7S3 cells, we aimed to investigate the effect of Sirt3 and E2 on cellular ROS levels and, on the one hand, found that E2 promoted mitochondrial ROS (mtROS) production in MCF-7C cells $(p<0.001)$, and this effect was inhibited by ICI (Figure 4E, $p<0.001)$. On the other hand, both cytosolic and mtROS levels were significantly reduced in E2-treated MCF-7S3 cells as compared with their controls (Figure 4D,E and $p<0.001$ ). However, without E2 treatment, MCF-7S3 cells exhibited a significant rise in cytosolic ROS $(p<0.001)$ with a parallel decline in mtROS levels $(p=0.002)$. These results indicate that Sirt3 increases cytosolic ROS but abolishes E2-induced increase of both cytosolic and mtROS levels.

A

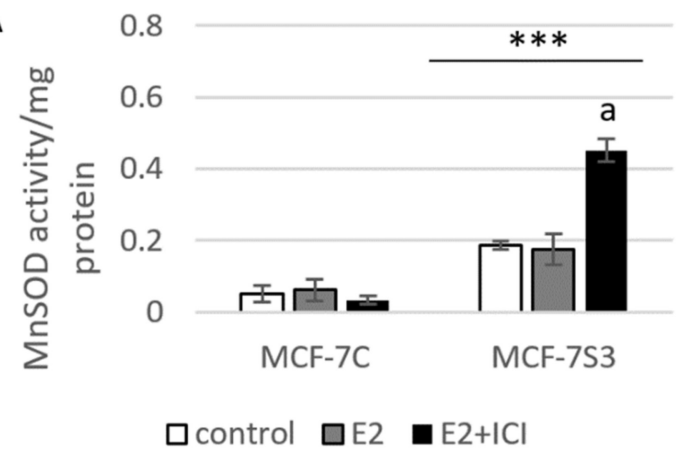

B

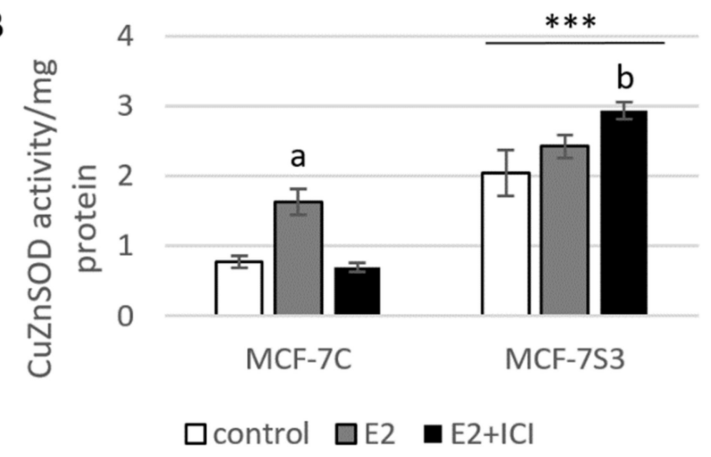

Figure 4. Cont. 


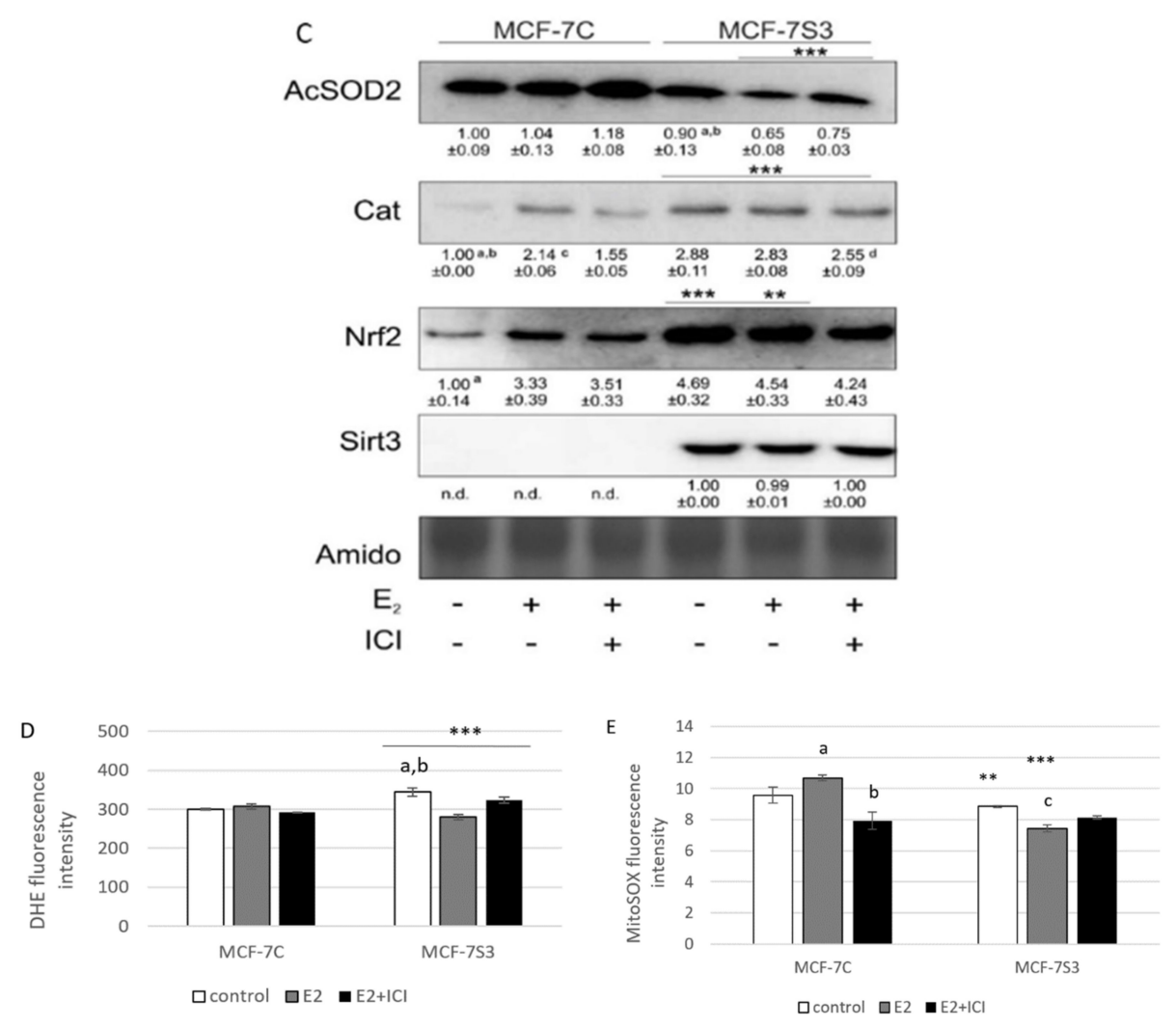

Figure 4. Sirt3 enhances antioxidative enzyme activities and cytosolic ROS but opposes E2-induced cytosolic and mtROS production. (A) For MnSOD activity, two-way ANOVA revealed a significant interaction effect between Sirt3 and treatment $\mathrm{F}(2,12)=53,853, p<0.001$, partial $\eta^{2}=0.900$; *** $p<0.001$ MCF-7S3 vs. MCF-7C. In MCF-7S3, higher activity in the E2 + ICI-treated vs. the other groups ( ${ }^{\mathrm{a}} p<0.001$ ); (B) For CuZnSOD activity, two-way ANOVA revealed a significant interaction effect between Sirt3 and treatment $\mathrm{F}(2,12)=75,435, p<0.001$, partial $\eta^{2}=0.952$; ${ }^{* * *} p<0.001$ MCF-7S3 vs. MCF-7C. In MCF-7C, higher activity in the E2-treated vs. the other groups ( ${ }^{a} \mathrm{p}<0.001$ ). In MCF-7S3, higher activity in E2 + ICI vs. other groups ( $\left.{ }^{\mathrm{b}} p<0.001\right)$. Results are shown as mean $\pm \operatorname{SD}(n \geq 3)$; (C) For immunoblots of proteins of antioxidative response, two-way ANOVA revealed significant interaction effect between Sirt3 and treatment on AcSOD2 F $(2,12)=11,691 ; p<0.01$, partial $\eta^{2}=0.916$; E2 and E2 + ICI-treated MCF-7S3 vs. MCF-7C (*** $p<0.001)$. In MCF-7S3, higher AcSOD2 in the control vs. the E2 $\left({ }^{\mathrm{a}} p<0.01\right)$ and $\mathrm{E} 2+\mathrm{ICI}$-treated $\left({ }^{\mathrm{b}} p<0.05\right)$. Two-way ANOVA revealed significant interaction effect between Sirt3 and treatment on Cat F $(2,12)=69,293, p<0.001$, partial $\eta^{2}=0.959$; ${ }^{* * *} p<0.001$ MCF-7S3 vs. MCF-7C. In MCF-7C, lower Cat in the control vs. E2 ( $\left.{ }^{\mathrm{a}} p<0.001\right)$ and E2 + ICI-treated $\left({ }^{\mathrm{b}} p<0.01\right)$; higher Cat in the E2 vs. E2 + ICI-treated ( $\left.{ }^{\mathrm{c}} p<0.01\right)$. In MCF-7S3, lower Cat in the E2 + ICI-treated vs. other groups ( $\left.{ }^{\mathrm{d}} p<0.01\right)$. Two-way ANOVA revealed significant interaction effect between Sirt3 and treatment on $\operatorname{Nrf} 2 \mathrm{~F}(2,12)=14,011, p=0.005$, partial $\eta^{2}=0.955$; the control $(* * * p<0.001)$ and E2-treated (** $p<0.01)$ MCF-7S3 vs. MCF-7C. In MCF-7C, lower Nrf2 in the control vs. the other groups ( $\left.{ }^{a} p<0.01\right)$. Results are shown as mean \pm SD normalized to the control MCF-7C $(n \geq 3)$. Amidoblack was used as a loading control; (D) For cytosolic ROS levels measured with DHE, two-way ANOVA revealed a significant interaction between Sirt3 and treatment $F(2,12)=805,710, p<0.001$, partial $\eta^{2}=0.996 ;{ }^{* * *} p<0.001$ MCF-7C vs. MCF-7S3 cells. In MCF-7S3, lower cytosolic ROS in E2 ( $\left.{ }^{\mathrm{a}} p<0.001\right)$ and E2 + ICI-treated ( $\left.{ }^{\mathrm{b}} p<0.01\right)$ vs. the control cells; (E) For MtROS levels measured with MitoSOX Red, two-way ANOVA revealed a significant interaction effect between Sirt3 and treatment $F(2,12)=94.860$, $p<0.001$, partial $\eta^{2}=0.941$; the control (** $\left.p=0.002\right)$ and E2-treated ( $\left.{ }^{* * *} p<0.001\right)$ MCF-7S3 vs. MCF-7C. In MCF-7C, higher mtROS in E2-treated vs. the control ( $\left.{ }^{\mathrm{a}} p<0.001\right)$; lower mtROS in E2 + ICI-treated vs. other groups ( $\left.{ }^{\mathrm{b}} p<0.001\right)$. In MCF-7S3, lower mtROS in E2-treated vs. other groups ( $\left.{ }^{\mathrm{c}} p<0.01\right)$. Results show the relative fluorescence intensity as the average geometric mean $\pm \operatorname{SD}(n \geq 3)$. 
3.5. Sirt3 Abolishes the Proliferative Effect of E2 on Colony Forming Capacity by Diminishing the E2-Induced DNA Synthesis of MCF-7 Cells

Our previous results showed that Sirt3 has an inhibitory role on several tumorigenic parameters of MCF-7 cells [8], therefore, we wanted to analyze its effect on the colony forming capacity in the presence or absence of E2. Since the MCF-7S3 cells were not able to produce colonies in white DMEM, we also performed this experiment in red DMEM with the addition of E2 and ICI. The observed difference in clonogenic capacity of the cells in red and white DMEM is not surprising, since it is well known that ER $\alpha$-positive breast cancer cells grow slower in phenol red-depleted media [17]. We observed a significant decrease in the colony forming ability of the MCF-7S3 cells in red DMEM as compared with the MCF-7C cells (Figure 5A,B and $p<0.001$ ). As expected for the red DMEM, in which the phenol red mimics the action of $\mathrm{E} 2$ and renders cells unresponsive to the proliferative effect of physiological concentrations of E2 [29], E2 addition failed to show any difference in the number of colonies as compared with the untreated cells. In white DMEM, the colony forming capacity of the MCF-7C cells was reduced to 5\% of their counterparts in red DMEM (Figure 5C,D). While E2 addition potentiated the growing capacity of the MCF-7C cells to nearly 70\% of the cells in red DMEM, the MCF-7S3 cells completely failed to form colonies, even with the addition of E2. The number of colonies treated with ICI declined in both media as compared with their corresponding controls $(p<0.001)$. Collectively, these results indicate that Sirt 3 attenuates the colony forming capacity of MCF-7 cells and abolishes the proliferative effect of E2 on MCF-7 cells.

Due to the observed reduced capacity of Sirt3-overexpressing cells to divide and form colonies, we investigated if Sirt3 affects cellular growth by inhibition of DNA synthesis using EdU Click-IT ${ }^{\circledR}$ assay (Thermo Fisher Scientific, USA). In white DMEM, E2 significantly promoted DNA synthesis in MCF-7C cells only (Figure 5E and $p<0.05$ ), whereas the ICI treatment effectively inhibited DNA synthesis in both cell lines $(p<0.05)$. These data collectively indicate that Sirt3 abolishes cellular proliferation by inhibiting E2-induced DNA synthesis.

A

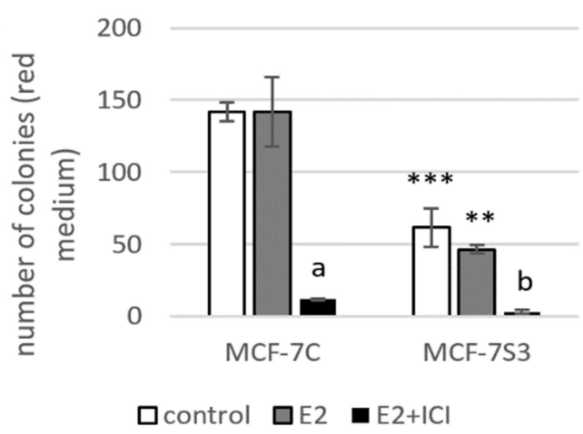

C

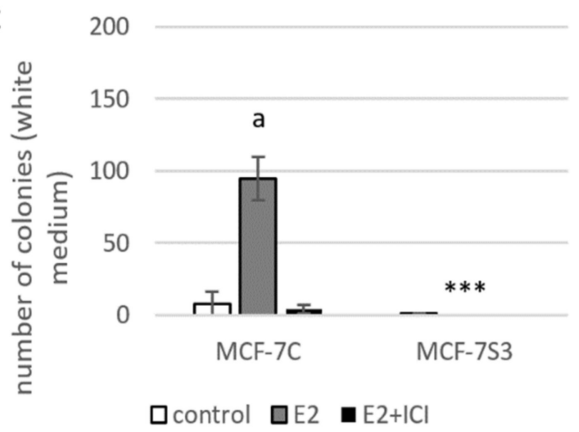

B

MCF-7C

MCF-7S3

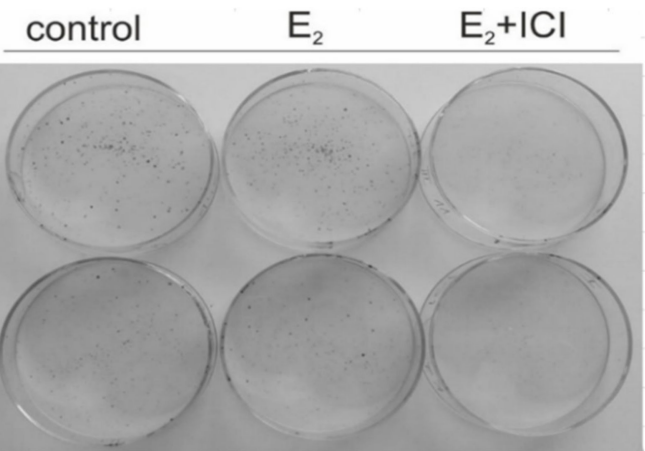

D

MCF-7C

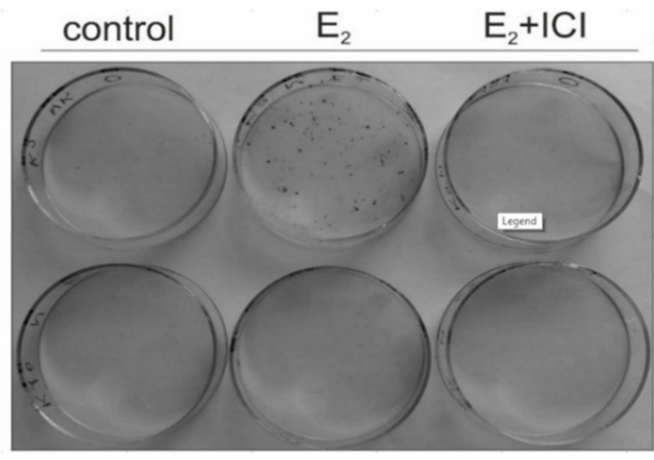

Figure 5. Cont. 


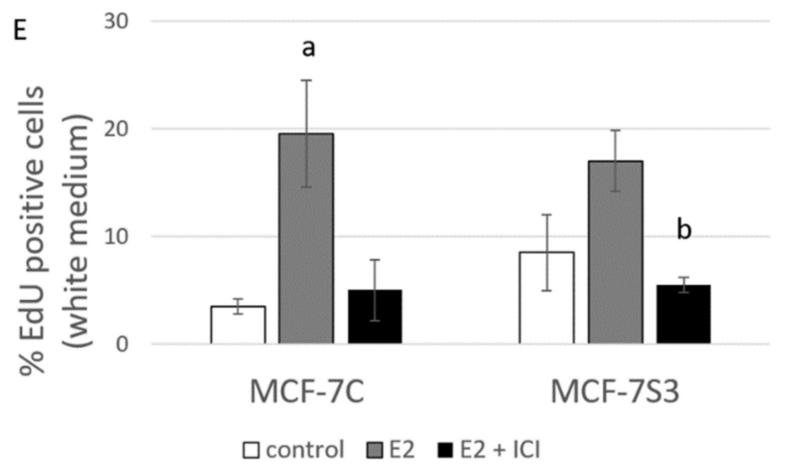

Figure 5. Sirt3 abolishes the proliferative effect of E2 on colony forming capacity by diminishing the E2-induced DNA synthesis of MCF-7 cells. (A) Histogram showing the number of colonies in red DMEM (CFU assay). Two-way ANOVA revealed significant interaction effect between Sirt3 and treatment on cellular clonogenic capacity $\mathrm{F}(2,15)=26,780 ; p<0.001$; partial $\eta^{2}=0.856$; the control $(* * *<0.001)$ and E2-treated (** $p<0.01)$ MCF-7S3 vs. MCF-7C. In MCF-7C, lower E2 + ICI-treated vs. other groups ( $\left({ }^{\mathrm{a}} p<0.001\right)$. In MCF-7S3, the lower E2 + ICI-treated vs. the other groups $\left({ }^{\mathrm{b}} p<0.001\right)$. Results are shown as mean \pm SD $(n \geq 3)$; (B) Representative plates of colonies grown in red DMEM stained with crystal violet; (C) Histogram showing the number of colonies in white DMEM (CFU assay). Two-way ANOVA revealed a significant interaction effect between Sirt3 and treatment on cellular clonogenic capacity F $(2,6)=52.397, p<0.001$, partial $\eta^{2}=0.946$, E2-treated (*** $p<0.001$ ) MCF-7S3 vs. MCF-7C. In MCF-7C, higher in the E2-treated vs. the other groups ( $\left.{ }^{a} p<0.001\right)$. Results are shown as mean \pm SD $(n \geq 3)$; (D) Representative plates of colonies grown in white DMEM stained with crystal violet; (E) DNA synthesis as a sign of proliferation in white DMEM measured with Click-iT ${ }^{\circledR}$ assay using flow cytometry. In MCF-7C, higher in the E2-treated vs. other groups ( $\left.{ }^{a} p<0.05\right)$. In MCF-7S3, lower in the E2 + ICI-treated vs. the E2-treated group $\left({ }^{\mathrm{b}} p<0.05\right)$. Results are shown as mean $\pm \mathrm{SD}$ $(n \geq 3)$.

\subsection{Sirt3 Induces Tumor-Suppressive Markers in MCF-7 Cells}

Since in our earlier study we observed higher levels of p53 in Sirt3-overexpressing cells [8], in this study, we investigated the level of p53 expression upon E2 treatment along with the expression of other p53-related proteins, such as apoptosis-inducing factor (AIF) and marker of DNA double strand breaks (phospho- $\gamma \mathrm{H} 2 \mathrm{AX}$ ). Consistent with our previous results, the p53 level was elevated in MCF-7S3 cells $(p<0.001)$. However, E2 and ICI had the opposite effect on the p53 expression level in Sirt3-overexpressed and control cells; while both treatments decreased p53 expression in MCF-7S3 cells $(p<0.01)$, they elevated the expression in the control MCF-7C cells (Figure 6A, $p<0.05$ for E2 and $p<0.001$ for E2 + ICI). AIF was significantly increased by both E2 and Sirt3 $(p<0.001)$, whereas DNA damage showed to be higher in the presence of Sirt3 $(p<0.001)$, however, was lowered by E2 addition $(p<0.001)$. This was confirmed by confocal microscopy which clearly demonstrated more DNA damage in the Sirt3-overexpressed cells, and less in the E2-treated groups of both cell lines (Figure 6B). In addition, we also noticed a higher number of micronucleated cells in the Sirt3-overexpressed line (Figure 6C), which is considered to be an indicator of genomic instability and usually predisposes cells to apoptosis [30]. The MCF-7S3 line displayed a higher frequency of micronucleated cells than the controls, with values similar to the $\mathrm{H}_{2} \mathrm{O}_{2}$-treated cells, which were used as a positive control for the induction of apoptosis [31]. Since earlier studies showed that upon both DNA damage and p53 activation, cell migration is decreased [32-34], we also checked the migration of the cells. The migration rate was reduced in the MCF-7S3 cells as compared with the controls $(p=0.007)$. Moreover, while migration was not affected by E2 in the control cells, E2 administration only slightly increased migration in the Sirt3 overexpressors (Figure 6D and Supplementary Figure S2). These data collectively demonstrate the tumor-suppressive role of Sirt3 in MCF-7 cells, which is partially restored by E2 treatment. 

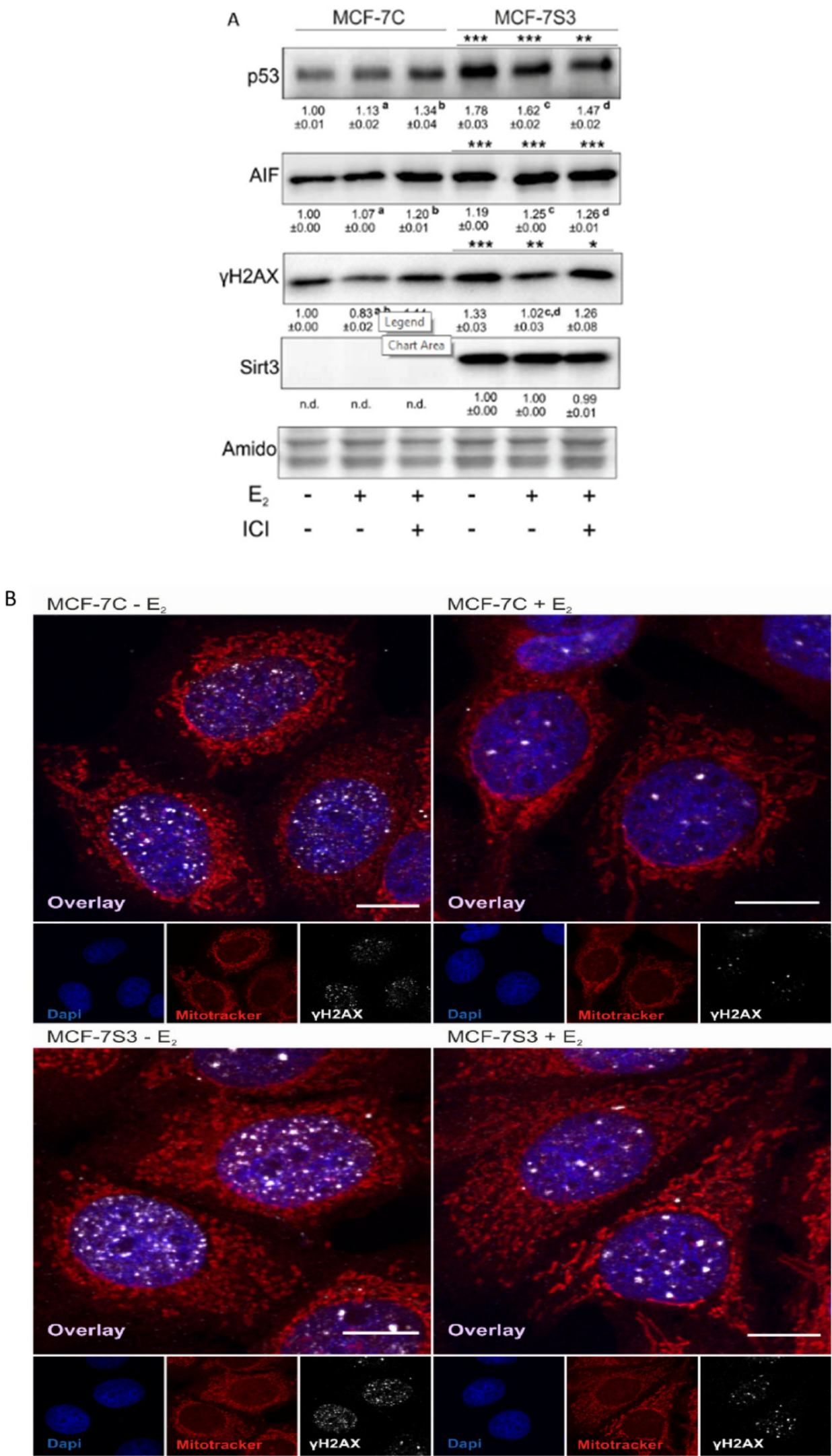

Figure 6. Cont. 
C

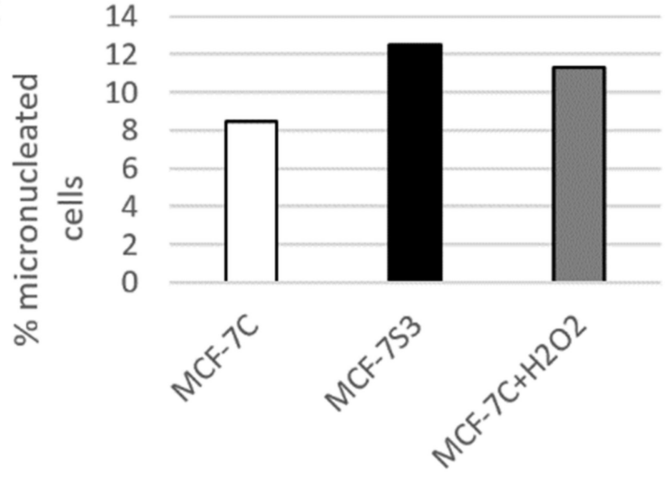

D

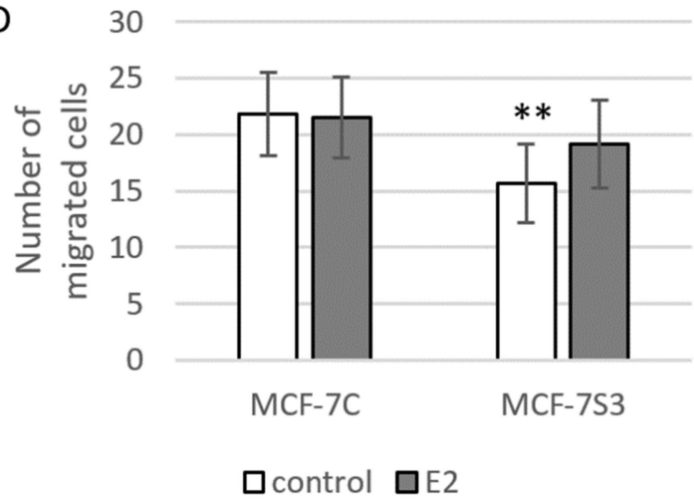

Figure 6. Sirt3 induces tumor-suppressive markers in MCF-7 cells. (A) Western blot analysis of proteins associated with tumor-suppressive function. Two-way ANOVA revealed a significant interaction effect between Sirt3 and treatment on the p53 level F $(2,12)=118.1, p<0.001$, partial $\eta^{2}=0.975$; higher in the MCF-7S3 control and E2-treated ( $\left.{ }^{* * *} p<0.001\right)$ and E2 + ICI-treated ( $\left.{ }^{* *} p<0.01\right)$ vs. MCF-7C. In MCF-7C, higher in the E2 ( $\left.{ }^{\mathrm{a}} p<0.05\right)$ and E2 + ICI-treated ( $\left.{ }^{\mathrm{b}} p<0.001\right)$ vs. the control. In MCF-7S3, lower in the E2 and E2 + ICI-treated vs. the control (c,d $p<0.01)$. For AIF, two-way ANOVA revealed a significant interaction effect between Sirt3 and treatment $\mathrm{F}(2,12)=187.56, p<0.001$, partial $\eta^{2}=0.984$; $* * * * 0.001$ MCF-7S3 vs. MCF-7C. In MCF-7C, higher in the E2 and E2 + ICI-treated vs. the control (a,b $p<0.001)$. In MCF-7S3, higher in the E2 and E2 + ICI-treated vs. the control (c,d $p<0.001)$. For phospho- $\gamma \mathrm{H} 2 \mathrm{AX}$, two-way ANOVA revealed significant interaction effect between Sirt3 and treatment $\mathrm{F}(2,12)=5.39$, $p<0.05$, partial $\eta^{2}=0.642$; the MCF-7S3 control $(* * *<0.001)$, E2 $(* * p<0.01)$, and E2 + ICI-treated $\left({ }^{*} p<0.05\right)$ vs. MCF-7C. In MCF-7C, lower in E2 vs. the control ( $\left.{ }^{a} p<0.05\right)$ and E2 + ICI-treated $\left({ }^{b} p<0.01\right)$. In MCF-7S3, lower in E2 vs. the control ( $\left.{ }^{c} p<0.001\right)$ and E2 + ICI-treated ( $\left.{ }^{\mathrm{d}} p<0.01\right)$. Results are shown as mean $\pm \mathrm{SD}(n \geq 3)$. Amidoblack was used as a loading control; (B) Confocal imaging of phospho- $\gamma \mathrm{H} 2 \mathrm{AX}$ signal abundance as a marker of DNA damage in MCF-7C and MCF-7S3 cells with or without E2 treatment. Bar represents $10 \mu \mathrm{m}$; (C) Graphical chart of frequency of micronucleated cells in MCF-7C and MCF-7S3 cells, as well as in MCF-7C cells treated with $\mathrm{H}_{2} \mathrm{O}_{2}$ as a positive control. The experiments were repeated at least three times and representative data are shown; (D) Graphical chart of number of migrated MCF-7C and MCF-7S3 cells with or without E2 treatment. Two-way ANOVA revealed a significant effect of Sirt3 on migration rate $\mathrm{F}(1,23)=1.812, p=0.007$, partial $\eta^{2}=0.279$; lower in MCF-7S3 vs. MCF-7C cells ( $\left.{ }^{* *} p=0.007\right)$. Results are shown as mean $\pm \operatorname{SD}(n \geq 3)$.

\subsection{Sirt3 Induces Disruption of ER $\alpha-p 53$ Interaction in MCF-7 Cells}

Due to the observed higher expression of p53 in MCF-7S3 cells, we hypothesized that Sirt3 can contribute to the lower proliferative capacity of the cells by increasing the p53 level. It is known that $\mathrm{ER} \alpha$ binds p53 and represses its function [35]. Since we observed no interaction between Sirt3 and p53 (Supplementary Figure S1), we tested to determine if Sirt3 affects p53 indirectly by altering the crosstalk between ER $\alpha$ and p53. Using coimmunoprecipitation, we demonstrated that in the MCF-7S3 cells ER $\alpha$ binding to p53 was markedly reduced as compared with the MCF-7C cells $(p<0.001)$ and E2 addition partially reverted this interaction (Figure 7). These results indicate that Sirt3-induced disruption of the ER $\alpha-\mathrm{p} 53$ interaction is partially reverted by E2 addition.

Collectively, on the one hand, the results show that Sirt3 improved the antioxidative response and mitochondrial fitness of the MCF-7 cells. On the other hand, it increased cytosolic ROS, DNA damage, along with p53, AIF, and ER $\alpha$ expression. Moreover, Sirt3 disrupted the p53-ER $\alpha$ interaction resulting in attenuation of tumor-promoting properties and proliferative effect of E2 in MCF-7 cells. 


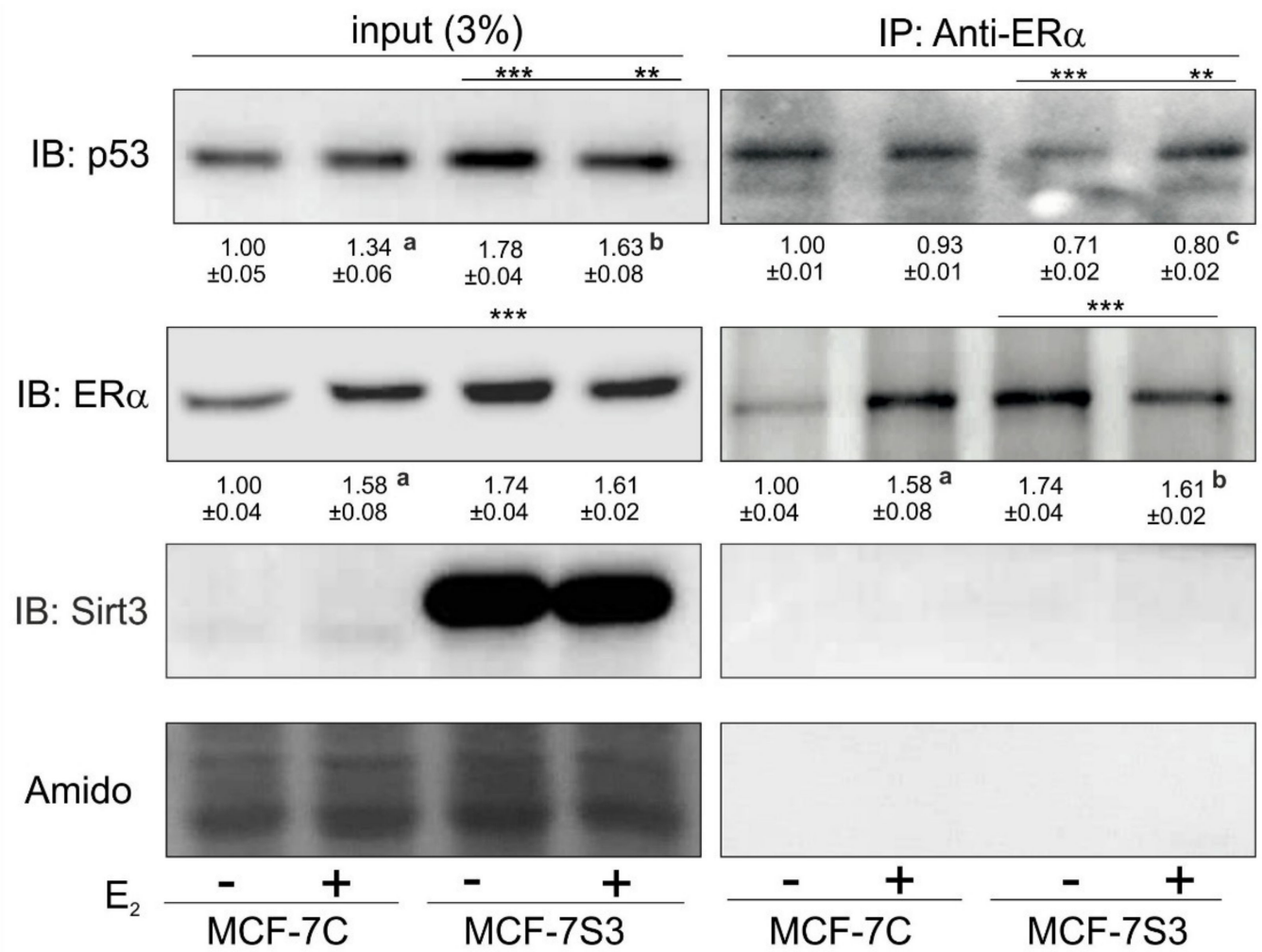

Figure 7. Sirt3 induces disruption of the ER $\alpha-$ p53 interaction in MCF-7 cells. Western blot analysis of coimmunoprecipitation experiment of ER $\alpha$ and its interacting partners using anti-ER $\alpha$ and anti-p53 antibody. For input p53, MCF-7C + E2 vs. MCF-7C ( $\left.{ }^{\mathrm{a}} p<0.001\right)$, MCF-7S3 + E2 vs. MCF-7S3 ( $\left.{ }^{\mathrm{b}} p<0.01\right)$, the MCF-7S3 control vs. MCF-7C (*** $p<0.001)$, MCF-7S3 + E2 vs. MCF-7C (** $p<0.01)$. For input $\mathrm{ER} \alpha, \mathrm{MCF}-7 \mathrm{C}+\mathrm{E} 2$ vs. MCF-7C (a $p<0.01)$, MCF-7S3 vs. MCF-7C (*** $p<0.001)$. For IP-ER $\alpha$, a control that IP was successful (MCF-7C + E2 vs. MCF-7C ${ }^{\mathrm{a}} p<0.001, \mathrm{MCF}-7 \mathrm{~S} 3+\mathrm{E} 2$ vs. MCF-7S3 ${ }^{\mathrm{b}} p<0.001$, and MCF-7S3 vs. MCF-7C (*** $p<0.001)$. For IP-Sirt3, a confirmation that there is no interaction between ER $\alpha$ and Sirt3. For IP-p53, two-way ANOVA revealed a significant interaction effect between Sirt3 and treatment on the p53 level F $(1,4)=64.47, p=0.001$, partial $\eta^{2}=0.942$; lower in the control $(* * * p<0.001)$ and the E2-treated (** $p<0.01)$ MCF-7S3 vs. MCF-7C. In MCF-7S3, lower in the control vs. the E2-treated cells ( $\left.{ }^{c} p=0.003\right)$. Representative blots are shown $(n \geq 3)$.

\section{Discussion}

The significance of Sirt3 in breast cancer cells lies in the fact that only $23 \%$ of normal breast tissue shows to be negative for Sirt3 expression, whereas even up to $72 \%$ of in situ breast lesions and $74 \%$ of invasive lesions are negative for the expression of Sirt3 [14]. Previously, we showed the tumor-suppressive role of overexpressed Sirt3 in human MCF-7 breast cancer cells, which are characterized by low Sirt3 expression [8]. In this study, we investigated if the tumor-suppressive effect of Sirt3 is mediated through the ER $\alpha$ signaling pathway in MCF-7 cells [3]. In this study, we report that a mitochondrial protein Sirt3, despite improving the mitochondrial function, induces DNA damage and tumor-suppressive factors, affects p53 by disruption of the ER $\alpha$-p53 interaction, reduces response of the MCF-7 cells to E2 treatment, and consequently inhibits the migration and clonogenic capacity of the cells.

The expression of ER $\alpha$ can be regulated by different cellular factors and mechanisms (reviewed by [36]) and, in our study, we found that there is significant upregulation of ER $\alpha$ expression in Sirt3-overexpressing cells (Figure 1B,C). Furthermore, Sirt3 silencing caused downregulation of ER $\alpha$ expression (Figure 1D), indicating the involvement of Sirt3 in the ER $\alpha$ expression level. Since Sirt3 is a mitochondrial protein and ER $\alpha$ is mostly localized in the nucleus [37,38], it is unlikely that they interact. Some earlier studies proposed the regulation of a small fraction of ER $\alpha$ by estrogen in mitochondria 
(reviewed by [39]), but these claims are still controversial. We were also not able to confirm interaction between Sirt3 and ER $\alpha$ (Supplementary Figure S1). Moreover, confocal microscopy confirmed, in our model, that $\mathrm{ER} \alpha$, indeed, does not reside inside mitochondria, and Sirt3 does not reside in the nucleus (Figure 2) or cytoplasm, as was already shown in our previous study [8]. Thus, we hypothesized that overexpressed Sirt3 indirectly regulates the expression of ER $\alpha$ in MCF-7 breast cancer cells. It is known that $\mathrm{ER} \alpha$ contains a nuclear localization signal for the transport into the nucleus, which happens 10 to $30 \mathrm{~min}$ after E2 stimulation (reviewed by [40]). Therefore, we investigated the nuclear level of $\mathrm{ER} \alpha$ as an indicator of its E2-stimulated activation. The fractionation experiments indicated that both MCF-7C and MCF-7S3 cells have functional ER $\alpha$ because it was successfully shuttled into the nucleus upon E2 treatment (Figure 1E). ICI, a compound that impairs the dimerization of ER- $\alpha$, an event that takes place after E2 binding and is essential for the nuclear localization of the receptor [41], led to receptor degradation (Figure $1 \mathrm{C}, \mathrm{E}$ ) and partially depleted its nuclear localization as judged by more cytoplasmic ER $\alpha$ (Figure 2). Altogether, these data confirmed that ER $\alpha$ in our system is activated by E2 and that ICI is a good control for analysis of the ER-dependent pathways.

Several studies have shown that E2 has the ability to increase mitochondrial function and biogenesis (reviewed in [42]), therefore, we explored whethe Sirt3 plays a role in E2-induced metabolic fitness of MCF-7 cells. As observed in Figure 3A,C, Sirt3 potentiated this inducing effect of E2 leading to increased metabolic activity, primarily as a result of the induced rise in SDH-A expression (Figure 3B) [26]. This is not surprising, considering that ER $\alpha$ is an essential estrogen receptor for most E2-mediated increases in respiratory chain proteins and antioxidant enzymes [43,44]. Furthermore, Sirt3 also induced expression of complex I (NDUFA9) and III (UQCRC2) and elevated mitochondrial potential (Figure 3C). The latter was further enhanced upon E2 addition, indicating that the E2-induced rise in mitochondrial potential is Sirt3 dependent.

Elevated ROS is a common hallmark of cancer progression and can activate oncogenic signals involved in cell proliferation [45,46], hence, we wanted to check the ROS status of our cell lines. In agreement with others [47], our results showed that E2 promoted mtROS production in MCF-7C cells, while ICI abolished this effect (Figure 4E), suggesting the involvement of the ER $\alpha$ receptor in the E2-induced production of mtROS. This is not surprising, since E2 plays a critical role in the development of breast cancer by altering the mitochondrial function and causing a shift towards higher mtROS levels [48]. Sirt3 is a mitochondrial protein involved in the regulation of mitochondrial oxidative pathways [28] and we tested to determine if it regulates E2-induced proliferation by affecting ROS levels. In Sirt3-overexpressing cells, we observed lower mtROS levels (Figure 4E) and hypothesized that this could be the result of a more efficient mitochondrial antioxidant enzyme system induced by Sirt3. The oxidative stress response is manifested through upregulated antioxidative enzymes such as SOD and Cat that are under the control of Nrf2, which is activated upon oxidative stress or increased ROS production (reviewed by [49]). Our results showed a significant increase of Nrf2, Cat, and SOD in the MCF-7S3 cells (Figure 4A-C), indicating that the Sirt3-induced antioxidative response is associated with enhanced metabolic activity of the cells. Contrary to the MCF-7C cells, the E2-treated Sirt3-overexpressed cells showed lowered levels of both cytosolic and mtROS (Figure 4D,E), suggesting that the E2-generation of ROS is attenuated by Sirt3. Since numerous data postulate that an increase in ROS generated after exposure to E2 contributes to the development of human breast cancer [50,51], our findings propose that Sirt3 can function as a tumor suppressor by activating antioxidative enzymes and attenuating the E2-induced ROS levels from both cytosolic and mitochondrial compartments.

Although the Sirt3-overexpressing cells demonstrated improved mitochondrial function and antioxidative enzyme system response, the opposite effect was observed on their proliferation and migration. Control of proliferation by estrogens is a very complex process based on E2 binding to ER $\alpha$ and subsequent regulation of target genes and concomitant activation of G1 to S phase progression [16]. In the case of non-invasive ER $\alpha$-positive MCF-7 cells that otherwise display reduced expression of Sirt3 protein [52], the overexpression of Sirt3 diminished their growth, suggesting that Sirt3 inhibits their tumorigenic properties [8]. Furthermore, this inhibitory effect of Sirt3 is enhanced in the white 
DMEM regardless of E2 treatment (Figure 5A-D), indicating again that Sirt3 attenuates the proliferative effect of E2 on these cells. Interestingly, the observation that Sirt3-overexpressing cells have higher metabolic activity (Figure 3A) seems opposite to the fact that they show lower proliferation (Figure 5). However, cell cycle arrest does not necessarily result in metabolic dysfunction. On the contrary, some stressors can even increase the metabolic activity [53]. The Sirt3-mediated inhibitory effect on E2-induced proliferation was also supported by the analysis of DNA synthesis where we showed that E2 promotes DNA synthesis to a lesser extent in the MCF-7S3 cells as compared with the MCF-7C cells (Figure 5E). ICI decreases BrdU incorporation irrespective of Sirt3, confirming previous findings of the anti-proliferative effect of ICI by inhibition of DNA synthesis [53].

The mechanism of the Sirt3 effect on the reduction of clonogenic capacity is still not clear but involves DNA damage accumulation observed as an increase in $\gamma \mathrm{H} 2 \mathrm{AX}$ phosphorylation. The increased DNA damage was accompanied by a higher frequency of micronucleated cells in Sirt3-overexpressed cells, which are characterized by small, extra-nuclear chromatin bodies that arise in dividing cells due to chromosome aberrations or genome mutations (reviewed by [30]), and therefore are used as an indicator of genomic instability. In addition to the observed higher DNA damage and more micronucleated cells, the Sirt3-overexpressed cells also showed lower migration capacity. Some of these effects were partially rescued by E2 addition (Figure 6 and Supplementary Figure S2). These observations indicate that Sirt3 overexpression is associated with excessive genomic instability of MCF-7 cells, which can be alleviated by E2 treatment but only to a limited extent. However, this is not sufficient to rescue tumorigenic properties of these cells.

Since, in our earlier study, we observed higher levels of p53 in MCF-7S3 cells [8], we hypothesized that Sirt3 contributes to lower cellular proliferative capacity by increasing the p53 level. The upregulation of p53 and the tumor-suppressive effect of Sirt3 was shown also in other types of cancers [54,55]. The p53 protein is a transcriptional regulator and tumor suppressor that activates target genes for cell cycle arrest, apoptosis, and DNA repair, and is stabilized within the nucleus upon DNA damage or oncogenic signals (reviewed by [56]). Furthermore, p53 balances mitochondrial respiration by inhibiting the glycolysis and promoting OXPHOS. Our results showed that p53 is indeed upregulated in Sirt3-overexpressing cells (Figure 6A), but not through the interaction between Sirt3 and p53 (Supplementary Figure S1). Consistently, the apoptosis inducing factor (AIF), known to be transcriptionally upregulated by p53 [57], was also upregulated in Sirt3 clones. AIF is a mitochondrial flavoprotein harboring numerous functions for efficient oxidative phosphorylation and cytoprotective role in the mitochondria [58,59]. However, it has the opposite effect on cell survival upon translocation to the nucleus, where it serves as a potent pro-apoptotic trigger [60], resulting in large-scale DNA fragmentation [61]. This is also in line with the observed higher frequency of micronucleated cells in Sirt3-overexpressing cells (Figure 6C). Studies have shown that ER $\alpha$ directly binds to p53 and represses its function, thus, affecting p53-mediated cell cycle arrest [62]. Since ER $\alpha$ binding to p53 results in inactivation of p53, disruption of this interaction by Sirt3 indicates the possible mechanism of the tumor suppressive role of Sirt3 in breast cancer. Our results suggest that this disruption of the ER $\alpha-\mathrm{p} 53$ interaction is partially rescued upon E2 addition (Figure 7). However, these E2-mediated effects are not sufficient for MCF-7S3 cells to reach the proliferation capacity of the control cells (Figure 5A-D). Furthermore, the observed overexpression of $\mathrm{ER} \alpha$ (Figure 1C) correlates well with the increased level of p53 (Figure 6A), which is associated with inhibition of cellular growth [63]. Finally, while p53 can enhance metabolic activity by promoting OXPHOS [56], at the same time it inhibits cell cycle progression and causes a suppressive effect on growth of cancer cells.

\section{Conclusions}

In conclusion, based on the results from this study, we report that Sirt3, despite improving the mitochondrial function of MCF-7 breast cancer cells, reduces their response to E2, affects p53 by disruption of the ER $\alpha-$ p53 interaction, and inhibits clonogenic cell growth. Furthermore, the tumor suppressive effects of Sirt3 could be partially reversed by E2 treatment, but this is not sufficient to 
rescue the full tumorigenic potential of these cells. Therefore, because the majority of breast cancers are negative for the expression of Sirt3, we conclude that by reverting its expression in MCF-7 cells, breast cancer cell normalization could be induced. Thus, Sirt3 should be considered to be a potential therapeutic measure for treating E2-dependent breast cancers.

Supplementary Materials: The following are available online at http://www.mdpi.com/2076-3921/9/4/294/s1, Table S1: Antibodies used in this study for Western blot analyses, Table S2: Antibodies used in this study for immunofluorescence analyses, Figure S1: Sirt3 does not interact with p53 or ER $\alpha$ in MCF-7 cells, Figure S2: E2 partially rescues reduced migration of MCF-7S3 cells.

Author Contributions: Conceptualization, M.P. (Marija Pinteric), I.I.P., and S.S.; Formal analysis, M.P. (Marija Pinteric), I.I.P., M.P.H., V.F., M.P: (Mladen Paradzik), B.L.J.P., A.D., I.C., and S.S.; Funding acquisition, T.B.; Investigation, M.P. (Marija Pinteric), I.I.P., M.P.H., D.P., D.M., and S.S.; Methodology, M.P. (Marija Pinteric), I.I.P., M.P.H., M.P: (Mladen Paradzik), B.L.J.P., A.D., I.C., D.P., D.M., T.B. and S.S.; Project administration, T.B.; Resources, T. B.; Software, I.I.P. and S.S.; Supervision, T.B. and S.S.; Validation, S.S.; Visualization, V.F.; Writing-original draft, M.P. (Marija Pinteric), I.I.P. and S.S.; Writing—review and editing, M.P. (Marija Pinteric), I.I.P., M.P.H., V.F., M.P: (Mladen Paradzik), B.L.J.P., A.D., I.C., D.P., D.M., T.B., and S.S. All authors have read and agreed to the published version of the manuscript.

Funding: This research was funded by the Croatian Science Foundation (HRZZ), grant no. IP-2014-09-4533 "SuMERA", and with the support of the Marie Curie Alumni Association.

Acknowledgments: The authors would like to thank Iva Pešun Međimorec and Marina Marš for their excellent technical contribution.

Conflicts of Interest: The authors declare no conflict of interest. The funders had no role in the design of the study; in the collection, analyses, or interpretation of data; in the writing of the manuscript, or in the decision to publish the results.

\section{References}

1. Zárate, S.; Stevnsner, T.; Gredilla, R. Role of estrogen and other sex hormones in brain aging. Neuroprotection and DNA repair. Front. Aging Neurosci. 2017, 9, 430. [CrossRef] [PubMed]

2. Trenti, A.; Tedesco, S.; Boscaro, C.; Trevisi, L.; Bolego, C.; Cignarella, A. Estrogen, angiogenesis, immunity and cell metabolism: solving the puzzle. Int. J. Mol. Sci. 2018, 19, 859. [CrossRef] [PubMed]

3. Holst, F.; Stahl, P.R.; Ruiz, C.; Hellwinkel, O.; Jehan, Z.; Wendland, M.; Lebeau, A.; Terracciano, L.; Al-Kuraya, K.; Jänicke, F.; et al. Estrogen receptor alpha (ESR1) gene amplification is frequent in breast cancer. Nat. Genet. 2007, 39, 655-660. [CrossRef] [PubMed]

4. Klinge, C.M.; Jernigan, S.C.; Mattingly, K.A.; Risinger, K.E.; Zhang, J. Estrogen response element-dependent regulation of transcriptional activation of estrogen receptors $\alpha$ and $\beta$ by coactivators and corepressors. J. Mol. Endocrinol. 2004, 33, 387-410. [CrossRef]

5. Musgrove, E.A.; Sutherland, R.L. Biological determinants of endocrine resistance in breast cancer. Nat. Rev. Cancer 2009, 9, 631-643. [CrossRef]

6. Reid, G.; Hübner, M.R.; Métivier, R.; Brand, H.; Denger, S.; Manu, D.; Beaudouin, J.; Ellenberg, J.; Gannon, F. Cyclic, Proteasome-mediated turnover of unliganded and liganded ER $\alpha$ on responsive promoters is an integral feature of estrogen signaling. Mol. Cell 2003, 11, 695-707. [CrossRef]

7. Torrens-Mas, M.; Pons, D.G.; Sastre-Serra, J.; Oliver, J.; Roca, P. SIRT3 silencing sensitizes breast cancer cells to cytotoxic treatments through an increment in ROS production. J. Cell. Biochem. 2016, 118, 397-406. [CrossRef]

8. Pinterić, M.; Skrinjar, I.; Sobočanec, S.; Hadžija, M.P.; Paradzik, M.; Dekanić, A.; Marinović, M.; Halasz, M.; Belužic, R.; Davidović, G.; et al. De novo expression of transfected sirtuin 3 enhances susceptibility of human MCF-7 breast cancer cells to hyperoxia treatment. Free. Radic. Res. 2018, 52, 672-684. [CrossRef]

9. Li, T.; Kon, N.; Jiang, L.; Tan, M.; Ludwig, T.; Zhao, Y.; Baer, R.; Gu, W. Tumor suppression in the absence of p53-mediated cell-cycle arrest, apoptosis, and senescence. Cell 2012, 149, 1269-1283. [CrossRef]

10. Oren, M.; Damalas, A.; Gottlieb, T.; Michael, D.; Taplick, J.; Leal, J.F.M.; Maya, R.; Moas, M.; Seger, R.; Taya, Y.; et al. Regulation of p53. Ann. N. Y. Acad. Sci. 2002, 973, 374-383. [CrossRef]

11. Lacroix, M.; Toillon, R.-A.; Leclercq, G. p53 and breast cancer, an update. Endocr-Relat. Cancer 2006, 13, 293-325. [CrossRef] [PubMed] 
12. Konduri, S.D.; Medisetty, R.; Liu, W.; Kaipparettu, B.; Srivastava, P.; Brauch, H.; Fritz, P.; Swetzig, W.M.; Gardner, A.E.; Khan, S.A.; et al. Mechanisms of estrogen receptor antagonism toward p53 and its implications in breast cancer therapeutic response and stem cell regulation. Proc. Natl. Acad. Sci. USA 2010, 107, 15081-15086. [CrossRef]

13. Rochefort, H.; Platet, N.; Hayashido, Y.; Derocq, D.; Lucas, A.; Cunat, S.; Garcia, M. Estrogen receptor mediated inhibition of cancer cell invasion and motility: An overview. J. Steroid Biochem. Mol. Boil. 1998, 65, 163-168. [CrossRef]

14. Desouki, M.M.; Doubinskaia, I.; Gius, D.; Abdulkadir, S.A. Decreased mitochondrial SIRT3 expression is a potential molecular biomarker associated with poor outcome in breast cancer. Hum. Pathol. 2014, 45, 1071-1077. [CrossRef]

15. Zhao, K.; Zhou, Y.; Qiao, C.; Ni, T.; Li, Z.; Wang, X.; Guo, Q.; Lu, N.; Wei, L. Oroxylin A promotes PTEN-mediated negative regulation of MDM2 transcription via SIRT3-mediated deacetylation to stabilize p53 and inhibit glycolysis in wt-p53 cancer cells. J. Hematol. Oncol. 2015, 8, 41. [CrossRef] [PubMed]

16. Dalvai, M.; Bystricky, K. Cell cycle and anti-estrogen effects synergize to regulate cell proliferation and ER target gene expression. PLoS ONE 2010, 5, e11011. [CrossRef] [PubMed]

17. Węsierska-Gądek, J.; Schreiner, T.; Maurer, M.; Waringer, A.; Ranftler, C. Phenol red in the culture medium strongly affects the susceptibility of human MCF-7 cells to roscovitine. Cell. Mol. Boil. Lett. 2007, 12, 280-293. [CrossRef]

18. Tristan, C.; Shahani, N.; Sedlak, T.W.; Sawa, A. The diverse functions of GAPDH: Views from different subcellular compartments. Cell. Signal. 2010, 23, 317-323. [CrossRef]

19. DiMauro, I.; Pearson, T.; Caporossi, D.; Jackson, M.J. A simple protocol for the subcellular fractionation of skeletal muscle cells and tissue. BMC Res. Notes 2012, 5, 513. [CrossRef]

20. Šarić, A.; Crnolatac, I.; Bouillaud, F.; Sobočanec, S.; Mikecin, A.-M.; Šafranko, Ž.M.; Delgeorgiev, T.; Piantanida, I.; Balog, T.; Petit, P.X.; et al. Non-toxic fluorescent phosphonium probes to detect mitochondrial potential. Methods Appl. Fluoresc. 2017, 5, 15007. [CrossRef]

21. Chehrehasa, F.; Meedeniya, A.C.; Dwyer, P.; Abrahamsen, G.; Mackay-Sim, A. EdU, a new thymidine analogue for labelling proliferating cells in the nervous system. J. Neurosci. Methods 2009, 177, 122-130. [CrossRef] [PubMed]

22. Totta, P.; Pesiri, V.; Marino, M.; Acconcia, F. Lysosomal function is involved in $17 \beta$-estradiol-induced estrogen receptor $\alpha$ degradation and cell proliferation. PLoS ONE 2014, 9, e94880. [CrossRef]

23. Chen, J.Q.; Delannoy, M.; Cooke, C.; Yager, J.D. Mitochondrial localization of ER $\alpha$ and ER $\beta$ in human MCF7 cells. Am. J. Physiol. Metab. 2004, 286, E1011-E1022. [CrossRef] [PubMed]

24. Yaşar, P.; Ayaz, G.; User, S.D.; Güpür, G.; Muyan, M. Molecular mechanism of estrogen-estrogen receptor signaling. Reprod. Med. Boil. 2016, 16, 4-20. [CrossRef] [PubMed]

25. Ko, B.H.; Paik, J.Y.; Jung, K.H.; Lee, K.H. 17ß-estradiol augments 18 F-FDG uptake and glycolysis of T47D breast cancer cells via membrane-initiated rapid PI3K-Akt activation. J. Nucl. Med. 2010, 51, 1740-1747. [CrossRef]

26. Rai, Y.; Pathak, R.; Kumari, N.; Sah, D.K.; Pandey, S.; Kalra, N.; Soni, R.; Dwarakanath, B.S.; Bhatt, A.N. Mitochondrial biogenesis and metabolic hyperactivation limits the application of MTT assay in the estimation of radiation induced growth inhibition. Sci. Rep. 2018, 8, 1531. [CrossRef]

27. Zorova, L.D.; Popkov, V.A.; Plotnikov, E.Y.; Silachev, D.N.; Pevzner, I.B.; Jankauskas, S.S.; Babenko, V.A.; Zorov, S.D.; Balakireva, A.V.; Juhaszova, M.; et al. Mitochondrial membrane potential. Anal. Biochem. 2018, 552, 50-59. [CrossRef]

28. Singh, C.K.; Chhabra, G.; Ndiaye, M.A.; Garcia-Peterson, L.M.; Mack, N.J.; Ahmad, N. The role of sirtuins in antioxidant and redox signaling. Antioxid. Redox Signal. 2018, 28, 643-661. [CrossRef]

29. Węsierska-Gądek, J.; Schreiner, T.; Gueorguieva, M.; Ranftler, C. Phenol red reduces ROSC mediated cell cycle arrest and apoptosis in human MCF-7 cells. J. Cell. Biochem. 2006, 98, 1367-1379. [CrossRef]

30. Hintzsche, H.; Hemmann, U.; Poth, A.; Utesch, D.; Lott, J.; Stopper, H.; Working Group “In vitro micronucleus test"; Gesellschaft für Umwelt-Mutationsforschung (GUM, German-speaking section of the European Environmental Mutagenesis and Genomics Society EEMGS). Fate of micronuclei and micronucleated cells. Mutat. Res. Mutat. Res. 2017, 771, 85-98. [CrossRef] 
31. Fenech, M.; Crott, J.; Turner, J.; Brown, S. Necrosis, apoptosis, cytostasis and DNA damage in human lymphocytes measured simultaneously within the cytokinesis-block micronucleus assay: Description of the method and results for hydrogen peroxide. Mutagenesis 1999, 14, 605-612. [CrossRef] [PubMed]

32. Hsu, F.-F.; Lin, T.-Y.; Chen, J.-Y.; Shieh, S.-Y. p53-Mediated transactivation of LIMK2b links actin dynamics to cell cycle checkpoint control. Oncogene 2010, 29, 2864-2876. [CrossRef] [PubMed]

33. Herraiz, C.; Calvo, F.; Pandya, P.; Cantelli, G.; Rodriguez-Hernandez, I.; Orgaz, J.; Kang, N.; Chu, T.; Sahai, E.; Sanz-Moreno, V. Reactivation of p53 by a cytoskeletal sensor to control the balance between DNA damage and tumor dissemination. J. Natl. Cancer Inst. 2015, 108, 289. [CrossRef] [PubMed]

34. Roger, L.; Gadea, G.; Roux, P. Control of cell migration: A tumour suppressor function for p53? Boil. Cell 2006, 98, 141-152. [CrossRef] [PubMed]

35. Liu, W.; Konduri, S.D.; Bansal, S.; Nayak, B.K.; Rajasekaran, S.A.; Karuppayil, S.M.; Rajasekaran, A.K. Estrogen receptor-a binds p53 tumor suppressor protein. J. Biol. Chem. 2006, 281, 9837-9840. [CrossRef]

36. Hua, H.; Zhang, H.; Kong, Q.; Jiang, Y. Mechanisms for estrogen receptor expression in human cancer. Exp. Hematol. Oncol. 2018, 7, 24. [CrossRef]

37. Gourdy, P.; Guillaume, M.; Fontaine, C.; Adlanmerini, M.; Montagner, A.; Laurell, H.; Lenfant, F.; Arnal, J.-F. Estrogen receptor subcellular localization and cardiometabolism. Mol. Metab. 2018, 15, 56-69. [CrossRef]

38. Levin, E.R.; Hammes, S.R. Nuclear receptors outside the nucleus: Extranuclear signalling by steroid receptors. Nat. Rev. Mol. Cell Boil. 2016, 17, 783-797. [CrossRef]

39. Klinge, C.M. Estrogens regulate life and death in mitochondria. J. Bioenerg. Biomembr. 2017, 49, 307-324. [CrossRef]

40. Cruz, A.C.T.; Pérez-Alvarado, I.A.; Ramírez-Jarquín, J.O.; Rocha-Zavaleta, L. Nucleo-cytoplasmic transport of estrogen receptor alpha in breast cancer cells. Cell. Signal. 2017, 34, 121-132. [CrossRef]

41. Avendaño, C.; Menéndez, J.C. Anticancer drugs that inhibit hormone action. In Medicinal Chemistry of Anticancer Drugs; Elsevier BV: Amsterdam, The Netherlands, 2008; pp. 53-91.

42. Klinge, C.M. Estrogenic control of mitochondrial function and biogenesis. J. Cell. Biochem. 2008, 105, 1342-1351. [CrossRef] [PubMed]

43. O'Lone, R.; Knorr, K.; Schaffer, M.E.; Martini, P.G.; Mendelsohn, M.E.; Jaffe, I.Z.; Karas, R.H.; Bienkowska, J.; Hansen, U. Estrogen receptors alpha and beta mediate distinct pathways of vascular gene expression, including genes involved in mitochondrial electron transport and generation of reactive oxygen species. Mol. Endocrinol. 2007, 21, 1281-1296. [CrossRef] [PubMed]

44. Chen, J.-Q.; Cammarata, P.R.; Baines, C.P.; Yager, J.D. Regulation of mitochondrial respiratory chain biogenesis by estrogens/estrogen receptors and physiological, pathological and pharmacological implications. Biochim. et Biophys. Acta (BBA)-Bioenerg. 2009, 1793, 1540-1570. [CrossRef] [PubMed]

45. Kumari, S.; Badana, A.K.; Malla, R. Reactive oxygen species: a key constituent in cancer survival. Biomark. Insights 2018, 13, 1-9. [CrossRef]

46. Schieber, M.; Chandel, N.S. ROS function in redox signaling and oxidative stress. Curr. Boil. 2014, 24, R453-R462. [CrossRef]

47. Parkash, J.; Felty, Q.H.; Roy, D. Estrogen exerts a spatial and temporal influence on reactive oxygen species generation that precedes calcium uptake in high-capacity mitochondria: implications for rapid nongenomic signaling of cell growth. Biochemistry 2006, 45, 2872-2881. [CrossRef]

48. Felty, Q.H.; Roy, D. Estrogen, mitochondria, and growth of cancer and non-cancer cells. J. Carcinog. $2005,4,1$. [CrossRef]

49. Vomund, S.; Schäfer, A.; Parnham, M.J.; Brüne, B.; Von Knethen, A. Nrf2, the master regulator of anti-oxidative responses. Int. J. Mol. Sci. 2017, 18, 2772. [CrossRef]

50. Penney, R.; Roy, D. Thioredoxin-mediated redox regulation of resistance to endocrine therapy in breast cancer. Biochim. et Biophys. Acta (BBA)-Bioenerg. 2013, 1836, 60-79. [CrossRef]

51. Okoh, V.O.; Garba, N.A.; Penney, R.B.; Das, J.; Deoraj, A.; Singh, K.P.; Sarkar, S.; Felty, Q.; Yoo, C.; Jackson, R.M.; et al. Redox signalling to nuclear regulatory proteins by reactive oxygen species contributes to oestrogen-induced growth of breast cancer cells. Br. J. Cancer 2015, 112, 1687-1702. [CrossRef]

52. Finley, L.W.; Carracedo, A.; Lee, J.; Souza, A.; Egia, A.; Zhang, J.; Teruya-Feldstein, J.; Moreira, P.I.; Cardoso, S.M.; Clish, C.; et al. SIRT3 opposes reprogramming of cancer cell metabolism through HIF1 $\alpha$ destabilization. Cancer Cell 2011, 19, 416-428. [CrossRef] [PubMed] 
53. McGowan, E.; Alling, N.; Jackson, E.A.; Yagoub, D.; Haass, N.K.; Allen, J.D.; Martiniello-Wilks, R. Evaluation of cell cycle arrest in estrogen responsive MCF-7 breast cancer cells: pitfalls of the MTS assay. PLoS ONE 2011, 6, e20623. [CrossRef]

54. Zhang, Y.-Y.; Zhou, L.-M. Sirt3 inhibits hepatocellular carcinoma cell growth through reducing Mdm2mediated p53 degradation. Biochem. Biophys. Res. Commun. 2012, 423, 26-31. [CrossRef] [PubMed]

55. Xiao, K.; Jiang, J.; Wang, W.; Cao, S.; Zhu, L.; Zeng, H.; Ouyang, R.; Zhou, R.; Chen, P. Sirt3 is a tumor suppressor in lung adenocarcinoma cells. Oncol. Rep. 2013, 30, 1323-1328. [CrossRef] [PubMed]

56. Moulder, D.E.; Hatoum, D.; Tay, E.; Lin, Y.; McGowan, E. The roles of p53 in mitochondrial dynamics and cancer metabolism: the pendulum between survival and death in breast cancer? Cancers 2018, 10, 189. [CrossRef] [PubMed]

57. Stambolsky, P.; Weisz, L.; Shats, I.; Klein, Y.; Goldfinger, N.; Oren, M.; Rotter, V. Regulation of AIF expression by p53. Cell Death Differ. 2006, 13, 2140-2149. [CrossRef]

58. Vahsen, N.; Cande, C.; Brière, J.-J.; Bénit, P.; Joza, N.; Larochette, N.; Mastroberardino, P.G.; Pequignot, M.O.; Casares, N.; Lazar, V.; et al. AIF deficiency compromises oxidative phosphorylation. EMBO J. 2004, 23, 4679-4689. [CrossRef]

59. Urbano, A.; Lakshmanan, U.; Choo, P.H.; Kwan, J.C.; Ng, P.Y.; Guo, K.; Dhakshinamoorthy, S.; Porter, A. AIF suppresses chemical stress-induced apoptosis and maintains the transformed state of tumor cells. EMBO J. 2005, 24, 2815-2826. [CrossRef]

60. Cregan, S.P.; Dawson, V.L.; Slack, R. Role of AIF in caspase-dependent and caspase-independent cell death. Oncogene 2004, 23, 2785-2796. [CrossRef]

61. Susin, S.A.; Lorenzo, H.K.; Zamzami, N.; Marzo, I.; Brenner, C.; Larochette, N.; Prévost, M.-C.; Boyko, A.; Kroemer, G. Mitochondrial release of caspase-2 and -9 during the apoptotic process. J. Exp. Med. 1999, 189, 381-394. [CrossRef]

62. Berger, C.E.; Qian, Y.; Liu, G.; Chen, H.; Chen, X. p53, a target of estrogen receptor (ER) $\alpha$, modulates DNA damage-induced growth suppression in ER-positive breast cancer cells*. J. Boil. Chem. 2012, 287, 30117-30127. [CrossRef] [PubMed]

63. Fernandez-Cuesta, L.; Anaganti, S.; Hainaut, P.; Olivier, M. Estrogen levels act as a rheostat on p53 levels and modulate p53-dependent responses in breast cancer cell lines. Breast Cancer Res. Treat. 2010, 125, $35-42$. [CrossRef] [PubMed]

(C) 2020 by the authors. Licensee MDPI, Basel, Switzerland. This article is an open access article distributed under the terms and conditions of the Creative Commons Attribution (CC BY) license (http://creativecommons.org/licenses/by/4.0/). 